\title{
Judíos y judeoconversos en el negocio de la lana y los paños en Soria: siglos XIV-XVII
}

\author{
Máximo Diago Hernando* \\ Instituto de Historia, CSIC \\ ORCID ID: https://orcid.org/0000-0003-2118-5086
}

Estudio sobre el papel que judíos y judeoconversos desempeñaron en la economía de la ciudad de Soria en un período de larga duración, desde el siglo XIv hasta fines del siglo XVII. Se basa en la valoración comparativa de los resultados de estudios monográficos previos, y en el análisis de una abundante documentación de archivo inédita de los siglos XVI y XVII. Se pone en conexión el arraigo de familias portuguesas de origen judeoconverso en Soria en las décadas finales del siglo XVI, fenómeno que hasta ahora no había sido objeto de valoración por parte de la historiografía, con las realidades previas de fuerte presencia judía y judeoconversa en esta ciudad. Se resalta que las actividades económicas en que despuntaron estos portugueses coinciden con las practicadas por judíos y judeoconversos en las centurias previas, todas ellas propias del grupo social convencionalmente identificado como «clase media».

PALABRAS ClaVE: Castilla; comercio de lana; manufactura pañera; comercio de paños.

Jews and Converted Jews in the Business of Wool Trade and Cloth ManuFACTURE IN SORIA FROM THE 14TH TO THE 17TH CENTURY.- Research about the role that Jews and Converted Jews played in the local economy of the Castilian town of Soria during a long period of time, from the fourteenth century to the end of the seventeenth century. It is based on the comparative analysis of the results of previous monographic works, and in the study of many unpublished archival documents from the sixteenth and the seventeenth centuries. The author highlights the connections between the establishment of Portuguese families of Jewish origin in the city of Soria in the last decades of the sixteenth century, that has so far remained unnoticed by the historiography, and the social and economic realities of the previous centuries in this Castilian town, characterized by the economic dynamism of the Jews, and of the Converted Jews. He highlights the fact that the Portuguese families established in Soria at the end of the sixteenth century were devoted to the same economic activities practiced by Jews and Converted Jews in this same town in the previous centuries. These activities were the usual ones for the members of the social group that we identify as "middle class."

Keywords: Castile; Wool Trade; Cloth Manufacture; Cloth Trade.

*maximo.diago@cchs.csic.es

Copyright: (C) 2020 CSIC. Este es un artículo de acceso abierto distribuido bajo los términos de la licencia de uso y distribución Creative Commons Reconocimiento 4.0 Internacional (CC BY 4.0). 


\section{INTRODUCCIÓN}

El comercio de lanas y de productos textiles, junto con la fabricación de paños elaborados con lanas de origen local, fueron actividades económicas de capital importancia para un gran número de ciudades de la Corona de Castilla durante el período preindustrial. El papel que los individuos de origen judío, y sus descendientes después tras su conversión al cristianismo, desempeñaron en su promoción fue notable, más relevante sin duda del que les correspondía por su peso relativo en el conjunto de la población.

Nuestro propósito en el presente trabajo es contribuir a avanzar en la comprensión del papel que estas actividades desempeñaron en las economías locales y regionales, al tiempo que profundizamos en la caracterización desde el punto de vista socioeconómico de las comunidades judía y judeoconversa de la Corona de Castilla. Hemos seleccionado para ello el caso de un único núcleo de población, la ciudad de Soria. Consideramos justificada su elección por el hecho de que fue el centro de una dinámica región productora de lanas de muy diversa calidad y precio, entre las que se contaban algunas de las más finas producidas en la Corona de Castilla para la exportación, y además contó en los siglos bajomedievales con una próspera y activa comunidad judía, de la cual muchas familias se convirtieron al cristianismo, sobre todo tras 1492.

Cuando, durante el reinado de Felipe II, el establecimiento en Castilla de familias de judeoconversos portugueses, muchas de ellas probablemente de ascendencia castellana, se aceleró, Soria figuró también entre los núcleos urbanos que atrajeron a estos inmigrantes. Fueron muy numerosos los portugueses de probable origen judeoconverso que acudieron a la ciudad del Duero a partir de las dos últimas décadas del siglo XVI a hacer negocios, entre los que el de la exportación de lanas finas ocupó un lugar descollante. Muchos de ellos no arraigaron en ella, pero resulta posible identificar un puñado de familias que fijaron su residencia entonces en esta capital de la Castilla nororiental, y engrosaron el grupo de negociantes local que tenía centrados sus intereses en el trato con lanas y tejidos y en la fabricación de paños. Nos ha resultado imposible de momento llegar a establecer conexiones entre estas familias y las de los judíos sorianos que se instalaron en Portugal tras 1492. Pero nos ha parecido interesante llamar la atención sobre el hecho de que 
cuando se instalaron en Soria retomaron las mismas actividades en que con anterioridad habían despuntado en esta misma ciudad los judíos.

\section{LOS JUDÍOS SORIANOS EN EL COMERCIO DE LANAS Y PAÑOS}

Pese a que el comercio de lanas fue una actividad económica fundamental para la economía soriana ya desde los últimos siglos medievales, apenas se ha conservado documentación que permita profundizar en su estudio para fechas anteriores al siglo XV. Y, ni siquiera en esta centuria las informaciones disponibles son abundantes. Pero, pese a su escasez, resulta muy sintomático que el contrato más antiguo de venta de lanas por ganaderos sorianos hasta ahora dado a conocer, fechado en septiembre de 1443, fuese otorgado precisamente por un mercader judeoconverso soriano, el escribano de la Universidad de la Tierra, Juan Rodríguez de Soria. En él varios pequeños y medianos señores de ganado trashumante de la aldea serrana de La Losilla, cerca de Magaña, se obligaron a entregarle en el siguiente esquileo de junio de 1444 pequeñas cantidades de lanas de sus propios rebaños, por las que recibieron adelantadas diversas cuantías de dinero ${ }^{1}$. Se trata de un modelo de contratación que se siguió practicando con asiduidad por los pequeños ganaderos trashumantes sorianos durante los siglos XVI y XVII, y parece probable que ya en el siglo Xv fuese habitual. La destrucción de la práctica totalidad de la documentación notarial soriana de esta centuria nos impide, sin embargo, corroborar esta hipótesis, y sobre todo convierte en imposible la tarea de identificar a los mercaderes vecinos de Soria que entonces traficaron con lanas. Pero insistimos en que no deja de resultar sintomático que precisamente el primero que ha quedado documentado sea un judeoconverso.

Por lo que toca a los judíos sorianos, las pruebas documentales de su destacado papel en el comercio de lanas son algo más tardías. Especial-

\footnotetext{
1 Contrato otorgado en La Losilla, 24-IX-1443, en AHN (=Archivo Histórico Nacional)-Nobleza, Osuna, 2244-10-9, pieza 20. Este contrato fue presentado como prueba documental por la ciudad de Soria para demostrar la pertenencia de Magaña y sus aldeas a su jurisdicción, cuando en la primera mitad del siglo xvi siguió pleito contra los descendientes de Juan de Luna para que le fuesen devueltos estos territorios.
} 
mente ilustrativa resulta la información aportada por un documento del año 1483. Recoge la denuncia presentada por varios de ellos ante la Monarquía contra la autoridad concejil, por haber introducido un nuevo impuesto sobre las operaciones de venta de lana. Se quejaron entonces de que ellos eran los principales perjudicados, porque en la ciudad solo se dedicaban a dicha actividad unos diez o doce judíos del aljama, y otros cinco o seis cristianos ${ }^{2}$.

Entre estos judíos, a juzgar por la información recopilada, no hubo ningún exportador de lanas a Flandes, Francia o Italia. Se centraron en el negocio de la intermediación, como vendedores de sacas de lana lavada para mercaderes exportadores, en su mayoría vecinos de la ciudad de Burgos, junto a algunos genoveses. Judíos como Bienveniste de Calahorra compraban en el otoño o primavera lanas a pequeños ganaderos, avanzándoles cantidades de dinero varios meses antes del esquileo, pagándoselas a precios más bajos. Estas lanas las lavaban y ensacaban, para revenderlas a mercaderes vecinos de la ciudad de Burgos, como Juan Alfonso de Sahagún y su hijo Andrés de Escobar, a quienes les concedían aplazamientos de pago, a cambio de exigirles precios más elevados, que los compradores llegaron a denunciar como usurarios ${ }^{3}$.

Junto con el comercio de lanas, el de paños de importación fue otra actividad en la que los judíos hispanos en general desempeñaron un activo papel, mayor del que por su simple peso demográfico les habría correspondido. Para el caso en concreto de los sorianos, la carencia de documentación impide hacer una valoración basada en informaciones documentales detalladas. Para el siglo XIV no se dispone en Soria de una fuente documental tan valiosa como los protocolos notariales que para numerosos años de las décadas centrales de dicha centuria se conservan en la cercana villa de Ágreda, y que han permitido comprobar que los judíos avecindados en ella fueron activos vendedores de paños, entre los

2 AGS (=Archivo General de Simancas), RGS (=Registro General del Sello), XI1483, fol. 103.

3 Vid. Máximo Diago Hernando, «El comercio de la lana en Soria en época de los Reyes Católicos», Celtiberia 78 (1989) págs. 25-75, y Enrique Cantera Montenegro, «Los judíos y el negocio de la lana en los obispados de Calahorra y Osma a fines de la Edad Media», en Judaísmo hispano: Estudios en memoria de José Luis Lacave Riaño, ed. Elena Romero (Madrid: CSIC, 2002) págs. 616-628. 
que figuraron en lugar destacado los de importación, procedentes de ciudades del sur de Francia, como Narbona ${ }^{4}$.

Para el siglo Xv la documentación aragonesa de los libros registro de cobro de derechos aduaneros de sus décadas centrales, confirma que los judíos desempeñaban un activo papel en el comercio de importación de tejidos en la Corona de Castilla en su sector soriano. En concreto resultan muy ilustrativas las noticias sobre adquisición de tejidos y otros muy variados productos por mercaderes judíos en las tiendas (botigas) que funcionaban en la ciudad aragonesa de Tarazona, que a continuación introducían en la región soriana. Los documentos no informan, sin embargo, sobre el lugar de avecindamiento de estos judíos, pero puede deducirse por indicios que había entre ellos vecinos de Soria, como podría ser el caso de Simuel Abenate o Yuçe Benacan ${ }^{5}$.

Para las décadas finales del siglo xv la documentación comienza a ser más abundante, y confirma que miembros de la comunidad hebrea soriana ocuparon un lugar destacado entre los mercaderes más emprendedores y activos de la Castilla nororiental. Pero no suele resultar generosa en aportar noticias que permitan identificar con detalle el género de mercancías con las que trataban. No así en otros núcleos urbanos del entorno, como Almazán, donde hemos podido confirmar la importancia que el trato con paños tuvo para Abraham aben Rodrique, judío adnamantino del que desciende el prolífico linaje de judeoconversos de los Lainez. Sabemos, en efecto, que dejó a su muerte una "botica" de paños y sedas en la plaza de Almazán, que se valoró en 3.000 ducados de oro, y una segunda "botica" de mercería en la misma plaza, a cargo de dos criados judíos ${ }^{6}$. También en otros núcleos de más marcado carácter rural, como la villa de

4 Vid. Agustín Rubio Semper, Fuentes Medievales Sorianas. Ágreda. 1 (Soria: Diputación Provincial, 1999) docs. 29, 59 y 66; Manuel Hurtado Quero, «Judíos de Ágreda. Estudio de una familia de prestamistas a mediados del siglo XIV», Celtiberia 73 (1987) págs. 155-160, y M. ${ }^{a}$ Pilar SENENT, «Más aportaciones para el estudio de la aljama hebrea de la villa de Ágreda», Espacio, Tiempo y Forma. Historia Medieval 15 (2002) págs. 271-285.

5 Archivo de la Diputación de Zaragoza, manuscritos 6, 7 y 12. Libros de collidas de las generalidades del aduana de Tarazona.

6 Vid. Máximo Diago Hernando, «El ascenso de los judeoconversos al amparo de la alta nobleza en Castilla después de 1492: el caso de Almazán», Sefarad 74:1 (2014) págs. 145-184: 170. 
Calatañazor, del señorío de los Padilla, está constatada la presencia de judíos que trataban con paños. Así, poco antes de decretarse la expulsión en 1492, a unos que eran vecinos de esta villa soriana les fueron tomados cuarenta paños que llevaban a vender a la feria de Medina del Campo ${ }^{7}$. Por su parte Sento Beque y Simuel Gatyel, ambos vecinos de Calatañazor, fueron acusados por un campesino, vecino de Cascajosa, por haberles vendido ciertos paños $a$ logro, es decir, cobrándole precios usurarios ${ }^{8}$.

\section{JUDEOCONVERSOS SORIANOS EXPORTADORES DE LANAS EN EL SIGLO XVI}

Pese a la importancia de la región de Soria como productora de lanas de gran finura, solo superadas en calidad por las llamadas segovianas leonesas que ponían en el mercado propietarios de otras comarcas del reino, para las que existía una vigorosa demanda en los mercados internacionales, lo cierto es que la comunidad mercantil de la ciudad del Duero no contó entre sus miembros con muchos exportadores propiamente dichos ${ }^{9}$. Era el negocio de la exportación el más lucrativo, por los elevados precios que en los mercados de destino estaban dispuestos a pagar los fabricantes pañeros, pero para invertir con éxito en el mismo era preciso contar con una extensa red de contactos a nivel internacional, y con una solvente capacidad financiera, con la que afrontar los riesgos asociados a las operaciones de transferencia de capitales entre países muy alejados entre sí, con diferentes sistemas monetarios, que además solían tener vedada la saca de moneda. Para el siglo xv la documentación no aporta noticias que permitan identificar entre los vecinos de Soria a ningún exportador lanero. Hay que esperar al siglo XVI para encontrar

7 AGS, RGS, VI-1492, fol. 295.

8 AGS, RGS, VII-1485, fol. 85. Y AChV (=Archivo de la Real Chancillería de Valladolid), RE (=Registro de Ejecutorias), 16-3 (5-VIII-1488).

9 Vid. Máximo Diago Hernando, «L'accès au pouvoir local dans une région castillane tournée vers l'exportation. Soria aux xve et xvie siècles», en Circulations maritimes. L'Espagne et son Empire (xvie-XVIIIe siècle), eds. Michel Bertrand y JeanPhilippe PRIOTti (Rennes: Presses Universitaires de Rennes, 2011) págs. 137-158 y «Mercaderes exportadores de lanas en la ciudad de Soria durante los siglos XVI y XVII», Celtiberia 103 (2009) págs. 5-60. 
las primeras, que en líneas generales son escasas, puesto que el grueso de las exportaciones las realizaron mercaderes foráneos, encabezados en dicha centuria por los burgaleses. Llama la atención advertir, sin embargo, que entre los pocos mercaderes sorianos que a lo largo de este próspero siglo se embarcaron en empresas exportadoras de lanas, la presencia en términos relativos de judeoconversos es notable. El primer ejemplo destacado nos lo proporciona la familia Beltrán, sin duda la que protagonizó el proceso de ascenso social y político más exitoso entre los descendientes de judíos en la ciudad del Duero después de 1492. A ella pertenece Antonio Beltrán, señor de la villa de Tejado por compra que efectuó a un segundón del linaje de los Mendoza, que fue judío durante su infancia, al igual que sus padres y hermanos. Despuntó como exportador de lanas a Flandes, como nos confirman en primer lugar las declaraciones de varios testigos en 1516, quienes coincidieron en afirmar que «era hombre muy rico que tenía fama de poseer más de 30.000 ducados en dinero y en sacas de lana que envía a Flandes» ${ }^{10}$. Un inventario de bienes del año 1547 confirma, por otra parte, que eran muchas y de envergadura las deudas que con él tenían contraídas personas avecindadas o estantes en Flandes ${ }^{11}$. Pero no se limitó a negociar en el mercado flamenco, entonces el principal destino de las lanas sorianas. También tenemos noticia de que operó en el mercado italiano. En concreto en 1517 envió cierta cantidad de sacas de lana a la ciudad de Florencia, consignadas a Lanfedrino Lanfedrini y compañía, con sede en la capital toscana, para que las vendiesen en su nombre y le acudiesen después a él en Castilla con el producto obtenido de su venta ${ }^{12}$.

Los descendientes de Antonio Beltrán, aunque no abandonaron del todo el comercio de lanas, se fueron apartando poco a poco del negocio mer-

10 AGS, EMR (=Escribanía Mayor de Rentas), Hojas e Informaciones, leg. 577-1.. Vid. Máximo Diago Hernando, «El ascenso sociopolítico de los judeoconversos en Castilla en el siglo XVI. El ejemplo de la familia Beltrán en Soria», Sefarad 56:2 (1996) págs. 227-250.

11 Este inventario se encuentra en AHPS (=Archivo Histórico Provincial de Soria), C. 3519-7. Las cantidades debidas por estos deudores de Flandes eran muy elevadas. Juan de Bilbao debía por una partida 3.424.900 mrs. y por otra 2.683.958 mrs.

12 Se informa sobre el complejo procedimiento que se siguió para cobrar en Castilla el dinero obtenido de la venta en Florencia en Archivo Histórico Provincial de Valladolid, 7840-216, Medina del Campo, 20-VII-1519. 
cantil para adoptar el modo de vida propio de los caballeros rentistas. Pero otros judeoconversos que cabe adscribir a las clases medias ocuparon el hueco dejado por ellos en Soria, aunque la documentación no siempre permite identificarlos con la precisión y rigor deseable. Entre ellos estarían los hermanos Núñez, que participaron en operaciones de exportación de lanas a Normandía, sobre las que ya se ha tratado en otras ocasiones. Para evitar prolijidad, vamos aquí a limitarnos a añadir el ejemplo ilustrativo de Juan Garcia de Tardajos, personaje que destaca como exponente emblemático de la "pluriactividad" propia de los miembros de la "clase media" soriana de aquellas centurias. Tenemos noticia, en efecto, de varias operaciones de exportación de lanas a Italia, en concreto a Florencia, que realizó a finales del siglo XVI, en un momento en que las graves dificultades que afectaron a las exportaciones a los países atlánticos propiciaron una reorientación de las lanas sorianas hacia el mercado italiano. Así, con anterioridad a 1597 remitió sacas de lana a Florencia a las casas de Juan Luis Vitoria y Juan López de Oreitia, por un lado, y de Antonio Buelta y Juan González de Albelda por otro, que le fueron pagadas con posterioridad mediante la cesión de un juro al quitar de $3.070 .084 \mathrm{mrs}$. de principal y $219.343 \mathrm{mrs}$. de renta anual ${ }^{13}$. Y en los años siguientes continuó dirigiendo lanas hacia ese mercado, como demuestran los numerosos contratos concertados con carreteros para su transporte a Alicante, y las noticias sobre el cobro de letras despachadas en Florencia ${ }^{14}$. Por lo que toca a los mercados atlánticos tampoco los dejó desatendidos, aunque las operaciones sobre las que estamos informados son de menor envergadura. En concreto en 1581 trató con un mercader francés de Toulouse, Guillermo de Lestrada, el trueque de 247 arrobas y media de lana puestas en Bilbao por 22 cargas y media de pastel, recibidas en esta misma villa portuaria ${ }^{15}$. Más adelante, aprovechando sus contactos con un mercader portugués llamado Antonio Brandon, efectuó un pequeño envío de sacas de lana a Rouen para que se las vendiese allí el también portugués Francisco Méndez Soto ${ }^{16}$.

13 AHPS, PN (=Protocolos Notariales), 259-528-28.

14 AHPS, PN, 209-429-167. Varios contratos con carreteros en AHPS, PN, 210-430. Sobre el cobro de una letra fechada en Florencia, 15-XII-1601, AHPS, PN, 137-288-310.

15 AHPS, PN, 82-186-292.

16 En Soria, 23-VIII-1612, María de Soria, viuda de Juan García de Tardajos, hace constar que su difunto marido había enviado a Rouen por hacienda propia, aunque por 


\section{JUdEOCONVERSOS EMPRESARIOS PAÑEROS EN EL SIGLO XVI}

La ciudad de Soria no figuró en el selecto grupo de los principales centros manufactureros de paños de la Corona de Castilla en los períodos bajomedieval y moderno. Se trató de una manufactura introducida en fecha relativamente tardía ${ }^{17}$, y no alcanzó el grado de desarrollo de otras ciudades, como Segovia, Palencia o Cuenca, por citar solo unas pocas. Pero, a pesar de ello, fue una actividad fundamental desde el punto de vista económico y social para la ciudad, destacando como la principal proveedora de puestos de trabajo y medios de subsistencia para la población urbana. La contribución que los judíos pudieron realizar en el período medieval al desarrollo de esta actividad resulta muy difícil de valorar, por el carácter escueto de la documentación conservada. Solo disponemos de unos pocos indicios que sugieren, al margen de los que desempeñaron funciones modestas como artesanos del textil, algunos también pudieron erigirse en auténticos empresarios. Desde este punto de vista hay que llamar la atención sobre el hecho de que hubo judíos entre los propietarios de tintes a orillas del Duero ${ }^{18}$.

Cuando la documentación comienza a resultar bastante más abundante, y permite profundizar en el análisis del funcionamiento de la manufactura pañera soriana, podemos confirmar el hecho de que entre los que como empresarios más contribuyeron al desarrollo de dicha manufactura en la ciudad del Duero hubo algunos descendientes de judíos. Desde esta perspectiva la familia que más abundantes y concluyen-

orden de Antonio Brandon, 18 sacones y medio de lana estremeña lavada, que recibió en Rouen Francisco Méndez Soto. Estaba pendiente el ajuste de la operación; $c f$. AHPS, PN, 345-642-682.

17 Las últimas aportaciones sobre los orígenes de la manufactura de paños en Soria, pueden verse en Máximo Diago Hernando, «La ciudad de Soria como centro manufacturero durante el período bajomedieval», Espacio, Tiempo y Forma. Historia Medieval 22 (2009) págs. 65-89.

18 Un judío llamado Ysaque el portugués, que marchó a Portugal en 1492 y no regresó, dejó en confianza el tinte del que era propietario en Soria a su amigo Hernando de Garnica, el viejo; $c f$. Carlos Carrete Parrondo, El tribunal de la Inquisición en el obispado de Soria (1486-1502) (Salamanca: Universidad Pontificia de Salamanca, 1985) pág. 155 , doc. núm. 373. 
tes indicios nos ofrece es la de los García de Tardajos ${ }^{19}$. Los miembros de esta familia fueron propietarios de tintes, cedidos a renta a tintoreros vecinos de Soria, pero reservándose el derecho a poder utilizarlos cuando los necesitasen para teñir sus propios paños ${ }^{20}$. También mostraron interés por tener a su disposición molinos batanes, tomados a renta de sus propietarios, para subarrendarlos a bataneros profesionales, con la condición de que quedasen obligados a aderezarles los paños que les llevasen para enfurtir. Así, Juan Garcia de Tardajos, que había tomado a renta del bachiller Gutierre dos ruedas de batán en Chavaler, aldea próxima a Soria a orillas del Duero, las subarrendó a un batanero soriano llamado Pedro Jiménez, por 22 ducados al año. Conforme al contrato, este quedaba obligado a aderezarle toda la ropa que le diese y todas las «perchas» que trajese, pagándole por cada paño Contray 9 reales, por cada veintidoseno 7 reales, y por cada dieciocheno o catorceno 4 reales $^{21}$. La relevancia de la actividad de Juan García de Tardajos como fabricante de paños en la fase de su apresto en los batanes queda además corroborada por la abundancia de noticias sobre la adquisición por su parte de tierra de Magán o de los cerros de Madrid, transportada hasta Soria por carreteros ${ }^{22}$.

Por lo demás, la documentación proporciona gran cantidad de noticias que nos confirman que varias generaciones de la familia García de Tardajos, ejemplo paradigmático de la pluriactividad propia de la clase media soriana en el siglo XVI, reservaron a la fabricación de paños un lugar preeminente en sus inversiones. La saga se inicia con Andrés García de Tardajos, casado con Juana Morales, de quien tuvo a Juan García

${ }^{19}$ Los indicios que llevan a presumir el origen judeoconverso de esta familia pueden verse en Máximo Diago Hernando, «Los judeoconversos en Soria después de 1492», Sefarad 51 (1991) págs. 259-297: 275-276.

${ }^{20}$ Contrato de arrendamiento de un tinte a orillas del Duero por Juan García de Tardajos a Agustín de los Paños, tintorero, en Soria, 6-X-1566, por 4 años, por 25 ducados de renta al año; $c f$. AHPS, PN, 15-39-167. Contrato de arrendamiento por Juan García de Tardajos a Alonso de Ergueta, tintorero, de un tinte a orillas del Duero, por 4 años, por 27,5 ducados al año; $c f$. AHPS, PN, 205-422-55, Soria, 28-V-1597.

21 AHPS, PN, 15-39-169, Soria, 2-XI-1566.

22 Se trata de adquisiciones de grandes cantidades. Por ejemplo, según contrato de 2-III-1595, adquirió 600 arrobas de tierra de Magán, por un valor de 19.200 mrs. AHPS, PN, 200-409. 
de Tardajos, el mayor. Precisamente Juana Morales tras enviudar, y pese a que no sabía escribir, desarrolló una intensa actividad mercantil que ha justificado su caracterización por Díez Sanz como «mercadera de éxito» ${ }^{23}$. Su hijo Juan García de Tardajos, el mayor, formó compañía con ella, y tras su muerte siguió desplegando una incansable actividad, en el marco de una nueva compañía con su hijo homónimo, que tenía por objeto la fabricación de paños y el comercio de sedas y otros productos $^{24}$. Aunque el impacto de la crisis de finales del siglo XVI pasó factura al rendimiento de esta compañía, a medio plazo logró superar con éxito las dificultades. Así lo confirma el testamento de su hijo Juan García de Tardajos, el menor, casado con María de Soria, otorgado en $1612^{25}$.

\section{EXPLOTACIÓN DE GANADOS PARA LA PRODUCCIÓN DE LANA FINA}

A pesar de la importancia que las explotaciones ganaderas tuvieron para la economía soriana ya desde el período bajomedieval, no hay constancia de que los judíos sorianos fuesen propietarios de ganados de ningún tipo, ni trashumantes, ni riberiegos, es decir trasterminantes que pasaban a Navarra y Aragón en invierno, ni estantes de raza churra. Por el contrario, entre los judeoconversos volcados en el mundo de los ne-

23 Vid. Enrique DíEz Sanz, Soria. Un universo urbano en la España de los Austrias (Salamanca: Latorre Varios, 2009) págs. 260-263. La apreciación la confirma la noticia que aporta su hijo Juan García de Tardajos en su testamento de 1592, en que informa que a la muerte de su madre heredó de ella más de 1.000 ducados libres; $c f$. AHPS, PN, 206-423-294.

${ }^{24}$ En el testamento declara que tiene formada compañía con su hijo «de los paños que se labran, y de las mercadurías y de la tienda». Se refiere a una tienda ubicada en las casas donde él reside, la mitad de la cual pertenece a un mayorazgo fundado por su padre. Estas casas estaban al parecer en la Calle del Collado, la principal calle comercial de la ciudad; $c f$. AHPS, PN, 206-423-294, Soria, 10-VIII-1592.

25 AHPS, PN, 342-639-160, Soria, 10-I-1612. Apertura del testamento por la viuda. En él Juan García de Tardajos declaraba poseer un capital de 13.000 ducados. Añadió que al casar con María de Soria tenía 4.000 ducados, y por muerte de su sobrina María García de Vera, hija de su hermano Jerónimo García de Vera, heredó bienes troncales por valor de 1.200 ducados. A la muerte de su padre, Juan García de Tardajos, el mayor, heredó más de 8.000 ducados. 
gocios encontramos diversos individuos que llegaron a ser propietarios de cabañas de ganado trashumante, aunque prácticamente ninguno de ellos, por contraste con las familias nobles de la oligarquía, llegaron a dar origen a verdaderas sagas de ganaderos, bien porque sus inversiones tuvieron carácter ocasional, o bien porque, en algunos casos bien conocidos, no tuvieron descendientes que hacerse cargo de los rebaños.

Un buen ejemplo ilustrativo nos lo proporciona el varias veces aludido mercader judeoconverso Antonio Beltrán, señor de Tejado, quien compró en 1524 a un ganadero de origen yangüés, Martín de las Heras, toda su cabaña de ganado ovino trashumante, de en torno a dos millares de cabezas, con sus derechos de posesión en La Serena. Poco tiempo después, sin embargo, la volvió a vender a dos ganaderos avecindados en Cabrejas del Campo, aldea de la Tierra de Soria, a 12 reales por cabeza, mientras que el precio que él pagó efectivamente al yangüés, tras un largo litigio, fue de 9 reales por cabeza con posesión, por lo que obtuvo una importante plusvalía en la operación ${ }^{26}$. Fue, no obstante, la única incursión de este exitoso mercader y financiero en el negocio de la cría de ganados trashumantes, del que, por otro lado, también se mantuvieron al margen sus descendientes, que en el transcurso de muy pocas generaciones se terminaron convirtiendo en rentistas, propietarios de tierras y vasallos, que solo explotaron ganado de raza churra en régimen estante.

Otras familias sorianas aparecen también documentadas como propietarias de ganados trashumantes en el siglo XVI y las primeras décadas del XVII. Es el caso de la poliédrica, y repetidamente aludida, familia de los García de Tardajos, a la que pertenecía el licenciado Juan García, médico. Murió este próspero y dinámico mercader en 1630, cuando su viuda, María de Frías, procedió a la apertura de su testamento ${ }^{27}$. Para entonces debía ser ya muy anciano, y superar los 80 años, puesto que en 1608 declaró que tenía más de $60^{28}$. Dejó un patrimonio con valor estimado en el entorno de los 30.000 ducados, acumulados a lo largo de muchos años en que invirtió en el comercio de lanas finas de ganado

\footnotetext{
26 AChV, P.C. (=Pleitos Civiles), Taboada, Fenecidos, antiguo envoltorio 146-10.

27 AHPS, PN, 512-886-269, Soria, 25-X-1630.

28 AHPS, PN, 340-637-726.
} 
trashumante, destinadas a la exportación, aunque no consta que él fuese exportador, a diferencia de otros parientes cercanos suyos, como Juan García de Tardajos. Un rasgo singular de su perfil como hombre de negocios radica, no obstante, en que invirtió a gran escala en la explotación de rebaños de ganado ovino trashumante, productores de lana fina de la máxima calidad ${ }^{29}$. El tamaño de su explotación ganadera parece que experimentó fuertes oscilaciones, a juzgar por los datos disponibles sobre sus ventas de lanas, que en parte se pueden explicar por algunas bruscas desinversiones, que apuntan a un criterio especulativo en su gestión, con rápidas reacciones a la evolución de las condiciones del mercado. Así, desde este punto de vista, cabe destacar que en 1597, en un momento muy difícil para el negocio ganadero trashumante, vendió dos de los tres rebaños de ganado ovino que entonces poseía a dos mercaderes vecinos de la ciudad de Soria, con la curiosa condición de que los compradores podrían efectuar el pago de su valor mediante la entrega de lanas a un precio fijo de 15 reales por arroba, en lugar de mediante el abono de dinero al contado ${ }^{30}$. Después de realizar esta desinversión, volvería, sin embargo, a acumular cabezas de ganado en los primeros años del nuevo siglo, pues para el período 1619-29 tomó a renta dehesas para 3.106 cabezas de pasto en La Serena ${ }^{31}$. Y en 1615 llegó a vender 983 arrobas de lana de sus propios ganados, que solo podría haber reunido mediante el esquileo de cerca de 5.000 cabezas. Pero también es cierto que en otros ejercicios las lanas obtenidas de su propia cabaña se situaron en niveles muy inferiores. Así, no pasaron de 450 arrobas en 1607, 378 en 1611, 658 en 1614, y 619 en $1624^{32}$. Al margen de estas fuertes oscilaciones en la producción lanera de sus cabaña, un hecho que conviene destacar es que regularmente vendió las lanas de sus propios ganados a un precio superior al que obtenía de la reventa de otras que

${ }^{29}$ Sobre los mercaderes de la ciudad de Soria como propietarios de ganado trashumante entre los siglos XV y XVII, vid. Máximo Diago HernANDo, «Mercaderes propietarios de ganado trashumante en la cuadrilla mesteña soriana en los siglos XVI y XVII», Studia Historica. Historia Moderna 26 (2004) págs. 255-282.

30 AHPS, PN, 238-480-113, Soria, 26-III-1597.

31 AHPS, PN, 444-784-119.

32 Las cifras proceden de contratos de AHPS, PN; vid. Diago Hernando, «Mercaderes propietarios de ganado trashumante...», pág. 262. 
previamente había comprado a propietarios de muy variado perfil de la región soriana, entre los que abundaban los medianos y pequeños ganaderos de ámbitos rurales serranos. Esta diferencia de precio probaría que puso gran empeño en cuidar la reputación de su pila.

Dada la dificultad con la que se tropieza para demostrar con pruebas contundentes el origen judío de muchas de las familias de hombres de negocios de la Soria del siglo XVI para las que se dispone de indicios que permiten sospecharlo, no nos vamos a extender en aportar más ejemplos. Sí queremos referirnos, no obstante, a las figuras de los hermanos Francisco de Barnuevo, escribano, y Juan de Barnuevo, platero, quienes en los años finales del siglo XVI, y en las primeras décadas del siglo XVII despuntaron como mercaderes y hombres de negocios con una actividad muy diversificada, que realizaron importantes inversiones en el negocio ganadero trashumante, que les llevaron a figurar en el grupo de los mayores propietarios ganaderos de la ciudad de Soria, aunque a bastante distancia de las familias de la oligarquía noble ${ }^{33}$.

En cualquier caso, los ejemplos aducidos bastan para probar que, si bien es cierto que los judíos sorianos no mostraron interés por invertir en el negocio ganadero, pese a su intensa dedicación al trato con lanas, tras su integración en la sociedad cristiana, después de su conversión, cambiaron de estrategia. Como consecuencia durante los siglos XVI y XVII entre los numerosos mercaderes de la ciudad del Duero que invirtieron en la explotación de ganado hubo tanto judeoconversos como cristianos viejos. De ahí que, ante esta constatación, una vez más haya que insistir en la necesidad de desechar esa idea tan arraigada en la historiografía de que la ganadería trashumante mesteña fue un coto cerrado reservado para la nobleza "feudal" y las comunidades eclesiásticas.

\section{Arraigo de Judeconversos portugueses en Soria desde FINALES DEL SIGLO XVI}

Aunque muchos de los judíos que habían residido en Soria durante el reinado de los Reyes Católicos decidieron permanecer en la ciudad

33 Diago Hernando, «Mercaderes propietarios de ganado trashumante...», págs. 263-268. 
tras su conversión al cristianismo, a raíz de la publicación del decreto de expulsión de 1492, otros destacados mercaderes y financieros miembros de esta próspera comunidad optaron por exiliarse en reino de Portugal. Allí, poco después de su establecimiento, fueron forzados por el rey Manuel a adoptar la fe cristiana. Algunos de ellos han podido ser identificados con sus nuevos nombres cristianos gracias a la documentación conservada en el Archivo de Simancas ${ }^{34}$. Estas familias judías de origen soriano establecidas en Portugal mantuvieron contacto con sus parientes que habían quedado en Soria, habiéndose podido reconstruir trayectorias de individuos que regresaron a la ciudad del Duero en el transcurso de la primera mitad del siglo XVI, para fijar allí su vecindad. La de Álvaro Rodríguez, nacido en Portugal de un matrimonio de judíos sorianos exiliados, que ha sido reconstruida con detalle en otro lugar, resulta desde este punto de vista emblemática ${ }^{35}$. Y proporciona una buena prueba de que incluso los judeoconversos que cabría esperar más propensos a judaizar, como es el caso de los que nacieron en el seno de familias forzadas a la conversión en Portugal, y que regresaron a Castilla al cabo de varias décadas, también lograron finalmente su integración, incluso después de haber sufrido los efectos de las actuaciones de la Inquisición.

La intensificación de los contactos entre judeoconversos de Castilla y Portugal pertenecientes a las mismas familias durante la primera mitad del siglo XVI, no solo dio lugar al regreso a sus lugares de origen en Castilla de descendientes de los exiliados de 1492. También se produjo el fenómeno inverso, de instalación en Portugal de judeoconversos miembros de familias arraigadas en Castilla. Es el caso de una nieta del ya mencionado Ruy López Coronel, el judeoconverso vecino de Ágreda que se trajo consigo a tierras sorianas a Álvaro Rodríguez. Nos consta,

34 Vid. Máximo Diago Hernando, «Efectos del decreto de expulsión de 1492 sobre el grupo de mercaderes y financieros judíos de la ciudad de Soria», en Judaísmo hispano: Estudios en memoria de José Luis Lacave Riaño, ed. Elena Romero (Madrid: CSIC, 2002) págs. 749-764.

35 Más detalles sobre este caso, reconstruido a partir de documentación inquisitorial del tribunal de Cuenca, pueden encontrarse en Máximo Diago Hernando, «Luces y sombras en el proceso de integración de los judeoconversos en la región soriana durante los siglos XV y XVI», eHumanista/Conversos 6 (2018) págs. 1-18. 
en efecto, que en 1582 una nieta suya, María Coronel, estaba avecindada junto con su marido en Portugal ${ }^{36}$.

Tras la reunión de los reinos bajo una misma Monarquía en 1580 los contactos entre judeoconversos de Castilla y Portugal se incrementaron de forma notable. Los residentes en Portugal comenzaron a emigrar a tierras castellanas en un número creciente, y el proceso se aceleró durante el reinado de Felipe III $^{37}$. La región soriana también se vio afectada por esta corriente migratoria que afectó a toda Castilla, pues varias familias de origen portugués, según todos los indicios de origen judeoconverso, pasaron a instalarse en ella. Se trata mayoritariamente de familias que desplegaron una intensa actividad en el comercio de lanas, la fabricación de paños, la recaudación de impuestos, y otros negocios mercantiles y financieros propios de la que convencionalmente llamamos "clase media". La historiografía local no ha podido determinar todavía el origen de estas familias, ni si tenían ascendencia castellana, o incluso soriana. Cabe afirmar, sin embargo, que, salvo que nuevos hallazgos documentales demuestren lo contrario, estas nuevas familias de judeoconversos que arraigaron en Soria a partir de las últimas décadas del siglo XVI y durante el siglo XVII lograron integrarse sin apenas dificultades en el tejido social local. Lo hicieron hasta tal punto que algunos de sus miembros llegaron a pleitear después por que se les reconociese la condición hidalga, poniendo buen cuidado en ocultar sus antepasados judíos, a veces con argumentos inverosímiles.

${ }^{36}$ Así se recoge en una carta de poder que entonces otorgó a un portugués vecino de Chaves para que vendiese todos los bienes que le perteneciesen en Ágreda por herencia familiar; $c f$. AHPS, PN, 1496-2240-327 y 328.

${ }^{37}$ Entre las obras que han analizado el asentamiento de judeoconversos portugueses en Castilla en el siglo XVI, en especial en el ámbito de la submeseta sur, cabe destacar Raphael CARrasco, «Preludio del siglo de los portugueses. La Inquisición de Cuenca y los judaizantes lusitanos en el siglo XVI», Hispania 166 (1987) págs. 503-559 e «Inquisición y judaizantes portugueses en Toledo (segunda mitad del siglo XvI)», Revista d'Historia Moderna. Manuscrits. El mundo judio en la Edad Moderna. Siglos XVI y XVII 10 (1992) págs. 41-60. Para Andalucía cabe destacar la tesis doctoral de Marcos Rafael Cañas Pelayo, Los judeoconversos portugueses en el tribunal inquisitorial de Córdoba. Un análisis social (sS. XVI-XVII) (Universidad de Córdoba, 2016). Entre las numerosas obras de síntesis existentes, puede consultarse Juan Ignacio Pulido Serrano, Los conversos en España y Portugal (Madrid: Arco Libros-La Muralla, 2003). 
Sin ánimo de llevar a cabo un estudio genealógico, que está fuera de nuestras pretensiones, conviene, no obstante, dedicar unas pocas líneas a la identificación de estas familias. Entre ellas destaca, porque disponemos de información más detallada sobre su paso desde Portugal a Soria, la de los Oporto-Azambújar. En 1665 cinco miembros de esta familia realizaron diligencias para que no se les impusiese la obligación de contribuir en un impuesto cargado sobre los portugueses residentes en Castilla para que contribuyesen al esfuerzo bélico contra el nuevo autoproclamado rey de Portugal de la dinastía de Braganza. Alegaron entonces en su defensa que ellos habían vivido siempre en Soria, al igual que su abuelo y bisabuelo, quienes hacía más de cien años que se habían asentado en esta ciudad en tiempos del rey Felipe II $^{38}$. Parece que exageraron en el número de años, pues en otros documentos se fija el momento de la instalación de los primeros miembros de esta familia en Soria en los años que siguieron a los "movimientos" de Don Antonio, prior de Crato, que disputó sin éxito la corona portuguesa a Felipe II ${ }^{39}$. Fue entonces cuando Fernando de Oporto Azambújar se trasladó de Portugal a Soria con su mujer Francisca Rodríguez, y con su hijo primogénito Simón, quien había nacido en un lugar de Portugal llamado Casteldavid, que no hemos podido identificar de forma satisfactoria ${ }^{40}$. Después, este matrimonio tuvo otro hijo, llamado Francisco, que nació en Soria, y litigó por su hidalguía junto con su hermano mayor Simón. Pero, además, los documentos permiten identificar a otros dos hermanos más, en concreto un varón llamado Alonso Fernández de Oporto, y una mujer, Margarita, que casó con un judeoconverso portugués llamado Diego Rodríguez, que fue un hombre de negocios tan destacado como sus parientes de apellido Oporto. No obstante, este último, siguiendo una costumbre muy arraigada entre los de su "nación", no mantuvo su residencia en Soria de forma estable sino que pasó a avecindarse durante un período de tiempo en la villa de Pastrana, dinámico centro urbano, con notoria actividad mercantil y manufacturera, en especial en la rama de

38 AHPS, PN, 605-1028-215, Soria, 6-V-1665.

39 Interesan las declaraciones de testigos residentes en el reino de Portugal, en el pleito de hidalguía que siguieron en 1635 en la Chancillería de Valladolid los hermanos Francisco y Simón Fernández de Oporto Azambújar; cf. AChV, Hijosdalgo, 244-2.

${ }^{40}$ Hay en Portugal un lugar llamado Castelo de Vide, pero se localiza en el Alentejo. 
la seda, y que también acogió a portugueses entre sus vecinos en el siglo XVII ${ }^{41}$. Lo sabemos porque en 1621 su suegra, Francisca Rodríguez, viuda de Hernando de Oporto, declaró que este yerno, que entonces vivía en Pastrana, tenía intención de trasladar su casa y familia a la ciudad de Soria, y por este motivo había decidido entregar a su hija dote para que se pudiese sustentar mejor ${ }^{42}$. El cambio de residencia se llevó a efecto, y en la ciudad del Duero vivieron los hijos de este matrimonio, entre los que cabe destacar a Diego Rodríguez de Azambújar, activo hombre de negocios, que otorgó testamento en $1656^{43}$.

Hernando de Oporto, el primer miembro de la familia afincado en Soria, murió en 1605, pero su viuda Francisca Rodríguez le sobrevivió muchos años ${ }^{44}$. Dejaron numerosos descendientes en Soria, que estuvieron conectados por lazos de parentesco y negocios con otras familias originarias de Portugal, identificadas por los apellidos de Méndez, Rico, o Hergueta, entre otros. Para estas otras familias no disponemos de informaciones tan detalladas y explícitas sobre las circunstancias en que se produjo su paso de Portugal a Soria, aunque cabe deducir que también tuvo lugar durante el reinado de Felipe II. Es el caso de los Méndez, uno de los cuales, Baltasar Méndez, otorgó testamento en 1591, nombrando entre sus testamentarios a Hernando de Oporto. Una hija suya, María Méndez, casó con el hijo mayor de Hernando, Simón. Y su hijo Pablo Méndez desarrolló igualmente una intensa actividad empresarial, en diversas ramas de la economía en las que también despuntaron sus colegas de la "nación" portuguesa.

41 Vid. Erika Puentes Quesada, «Un linaje "portugués” en Pastrana. La familia de sederos de Simón Muñoz», Revista d'Historia Moderna. Manuscrits. El mundo judío en la Edad Moderna. Siglos XVI y XVII 10 (1992) págs. 157-182, y Juan Ignacio Pulido SERRANO, «Portugueses al amparo de la nobleza (La Inquisición contra los vasallos del duque de Pastrana acusados de judaísmo durante el siglo XVII», Historia y Genealogía 5 (2015) págs. 41-59.

42 AHPS, PN, 437-774-2, Soria, 4-I-1621. Efectivamente el traslado de residencia se produjo porque en los años siguientes Diego Rodríguez aparece en la documentación notarial como vecino de Soria que mantenía relaciones de negocios con judeoconversos portugueses de Burdeos; $c f$. AHPS, PN, 439-777-7, Soria, 10-I-1623.

43 AHPS, PN, 581-993-318, Soria, 31-V-1656.

${ }^{44}$ El inventario de bienes declarados por Francisca Rodríguez, en Soria, 14-XI1605, tras la muerte de su marido se encuentra en AHPS, PN, 294-578-44. 
Los enlaces matrimoniales que conectaron a todas estas familias prueban una fuerte tendencia endogámica. No hay lugar aquí para detallarlos. Como ilustración nos limitaremos a recordar que Simón de Oporto, casado en primeras nupcias con María Méndez, lo hizo en segundas con Águeda Hergueta, que Alonso de Oporto Azambújar casó con Águeda Rico, mientras que el mercader Juan Rico lo hizo con Francisca Méndez, hija de Baltasar Méndez. Al tratar sobre las actividades económicas en que despuntaron estas familias, tendremos ocasión a continuación de aportar más noticias sobre estos personajes.

\section{Comercio de LANAS}

El papel de primera fila que los judeoconversos procedentes de Portugal desempeñaron en el comercio de exportación de lanas finas de la Corona de Castilla a partir de las últimas décadas del siglo Xvi y durante todo el siglo XVII, es un hecho fundamental de la historia económica castellana que no resulta en absoluto desconocido para la historiografía, desde que le dedicara su atención el clásico Jonathan Israel ${ }^{45}$. Se ha prestado, no obstante, atención preferente a la caracterización de los grandes exportadores que eran a la vez principales financieros o asentistas al servicio de la Real Hacienda, del tipo de los Montesinos ${ }^{46}$ o los Cortizos ${ }^{47}$. Pero

45 Vid. Jonathan I. IsRaEL, Empires and Entrepots. The Dutch, the Spanish Monarchy and the Jews, 1585-1713 (London: Continnuum-3PL, 1990) y «El comercio de los judíos sefardíes de Amsterdam con los conversos de Madrid a través del suroeste francés», en Religión y Negocio. El sefardismo en las relaciones entre el mundo ibérico y los Países Bajos en la Edad Moderna, eds. Jaime Contreras, Bernardo J. GarCía García y Juan Ignacio Pulido Serrano (Madrid: Fundación Carlos de Amberes-Ministerio de Asuntos Exteriores, 2002) págs. 373-390. Sobre los judeoconversos de Amsterdam, interesa también Josef Kaplan, Judios nuevos en Ámsterdam (Barcelona: Gedisa, 1996).

46 Sobre esta familia de judeoconversos portugueses, interesa la exhaustiva monografía de Bernardo López Belinchón, Honra, Libertad y Hacienda (Hombres de negocios y judios sefardies) (Madrid: Universidad de Alcalá, 2001).

47 Sobre esta familia, que contó entre sus miembros algunos de los mayores exportadores de lanas del siglo XVII, como Manuel Cortizos y Sebastián Cortizos, vid. Carmen SAnz Ayán, «Consolidación y destrucción de patrimonios financieros en la Edad Moderna: Los Cortizos (1630-1715), en Fortuna y negocios. Formación y gestión de los grandes patrimonios (Siglos XVI-XX), eds. Hilario CaSAdo Alonso y Roberto Robledo 
estos, pese a su indudable importancia, solo representan la punta del iceberg. A ellos se ha de añadir una multitud de mercaderes de segunda fila, que han de ser identificados mediante la realización de estudios monográficos de alcance local y comarcal, del tipo de los ya realizados para ámbitos como el soriano, que aquí nos ocupa ${ }^{48}$, y también muy especialmente para la ciudad de Madrid, que reunió una comunidad de mercaderes de origen judeoconverso portugués muy numerosa ${ }^{49}$.

Complementando los trabajos ya dedicados con anterioridad al análisis del papel de los portugueses en el mercado lanero de la región soriana, interesa que nos centremos aquí en dar cuenta de la contribución a esta magna empresa mercantil de los que alcanzaron mayor grado de arraigo en la ciudad del Duero. Frente a sus "compatriotas" que, o bien nunca residieron en Soria, o bien solo lo hicieron de forma discontinua o esporádica, los que se hicieron vecinos de la ciudad del Duero, arraigando en ella con sus familias a lo largo de varias generaciones, desempeñaron por regla general un papel menos destacado en el gran comercio de exportación de lanas finas. No encontramos entre ellos apenas a exportadores de cierto relieve.

Las únicas operaciones de exportación de lanas, mediante recurso a sus contactos con otros portugueses residentes en los puertos franceses $\mathrm{u}$ holandeses, de las que tenemos noticia, son de escasa envergadura. Es el caso de la que menciona en su testamento de 1665 Alonso de Oporto, donde hizo constar que, junto con su primo Alonso de Oporto, tenía a pérdida o ganancia 7 sacones de añinos de 10 arrobas en Bayona en poder de Luis de $\mathrm{Paz}^{50}$.

HERNÁNDEZ (Valladolid: Ediciones Universidad de Valladolid, 2002) págs. 73-98 y «Procedimientos culturales y transculturales de integración en un clan financiero internacional: los Cortizos (siglos XVII y XVIII)», en Las redes del Imperio. Élites sociales en la articulación de la Monarquía Hispánica (1492-1714), dir. Bartolomé Yun CasaliLla (Madrid: Marcial Pons-Universidad Pablo de Olavide, 2009) págs. 65-96.

48 Vid. Máximo Diago Hernando, «La irrupción de los conversos portugueses en el comercio de exportación de lanas de la Corona de Castilla en el tránsito de los siglos XVI al XVII», Sefarad 70:2 (2010) págs. 399-434.

49 Vid. Nicolás Broens, Monarquía y capital mercantil: Felipe IV y las redes comerciales portuguesas (1627-1635) (Madrid: UAM Ediciones, 1989), y Markus ScHREIBER, Marranen in Madrid. 1600-1670 (Stuttgart: Steiner, 1994).

50 AHPS, PN, 707-1167-454, Soria, 29-X-1665. 
Sí ha quedado constancia, por el contrario, de alguna operación de cierta envergadura de reventa de sacas de lana lavada a mercaderes exportadores que operaban en los puertos castellanos del Cantábrico. Es el caso de la realizada por Pablo Méndez gracias a la intermediación de Fausto Ruiz de Retana, vecino de Vitoria, en 1610. Le envió a este 80 sacones de lana lavada fina con el encargo de que se los vendiese, como en efecto hizo. Firmó el contrato de venta el 6 de abril de 1610 con Pedro de Bulguesa, mercader francés residente en San Sebastián, obligándose a pagárselas a razón de $16.000 \mathrm{mrs}$. por cada saca de peso de 8 arrobas. El pago se efectuaría mediante la entrega de las mercancías de importación especificadas en el contrato ${ }^{51}$.

En el comercio de lanas finas de ganado trashumante el papel de los portugueses de Soria consistió, no obstante, de forma preferente en servir como corresponsales o factores a otros mercaderes de su misma nación, residentes en otras ciudades castellanas o de otros países europeos ribereños del Océano Atlántico. Así, por ejemplo, Diego Rodríguez de Azambújar mantuvo correspondencia con mercaderes laneros portugueses de gran talla tanto de Castilla, como Fernando de Montesinos $^{52}$ o Juan de Fonseca Cardoso ${ }^{53}$, como de otras plazas europeas, como Burdeos o Bayona ${ }^{54}$.

51 Ajuste de la cuenta de la operación presente en AHPS, PN, 324-616-102, Soria, 10-VII-1610.

52 Diego Rodríguez de Azambújar declaró en su testamento de 1659 que había tenido cuenta con Fernando de Montesinos, «por encomiendas que ha tenido suyas», y tenía en el lavadero de su primo Alonso de Oporto, unos «tercios de saquerío», parte de los cuales eran de Fernando de Montesinos y parte suyos; $c f$. AHPS, PN, 581-993-318, Soria, 31-V-1656. Sobre la importancia alcanzada como mercaderes y financieros por los Montesinos, judeoconversos portugueses, vid. López Belinchón, Honra, Libertad y Hacienda (Hombres de negocios y judios sefardies).

53 En 1653 unos arrieros se obligan a llevar desde Soria a Vitoria 24 cargas de lana lavada pertenecientes a Juan de Fonseca Cardoso, que están en poder de Diego Rodríguez Azambújar; cf. AHPM, 7973-170, Madrid, 8-II-1653.

${ }^{54}$ En su testamento declaró haber mantenido correspondencia con Frederico Filtre, vecino de Burdeos, y con Diego Rodríguez Cardoso, vecino de Bayona. Sobre la importancia de estas dos plazas francesas para el comercio de los judeoconversos portugueses entre Castilla y Holanda; $c f$. Bernardo LóPEz BeLINChón, «Sacar la sustancia del reino. Comercio, contrabando y conversos portugueses, 1621-1640», Hispania 209 (2001) págs. 1.017-1.050, e IsRAEL, «El comercio de los judíos sefardíes de Ámsterdam». 
Estos grandes exportadores habitualmente eran financieros poco familiarizados con la actividad ganadera trashumante, y ni siquiera eran expertos en valorar la calidad de las lanas, diferenciando grados de finura, para acertar en la fijación de precios. Por ello requerían de la colaboración de personas que trabajasen in situ, en las comarcas productoras de la lana, que se encargasen de la contratación con los ganaderos, y de la gestión de todas las tareas desde el esquileo hasta la conducción de las sacas de lana lavada a los puertos de embarque. En Soria, por su condición de cabecera de uno de los principales partidos mesteños, hubo muchos mercaderes que se dedicaron a esta actividad de servir de factores o corresponsales a los grandes exportadores. Y una importante novedad del siglo XVII respecto a la anterior centuria radica en que entre ellos hubo varios portugueses, miembros de familias que habían arraigado en la ciudad a fines del siglo XVI.

Estos portugueses pusieron en práctica estrategias de contratación muy diversificadas, y contrataron con todo tipo de ganaderos, desde los grandes propietarios de familias de la oligarquía noble, que vendían pilas de gran tamaño y reputación por la finura de las lanas, hasta los más modestos propietarios de ganado estante de raza churra de las pequeñas aldeas de las comarcas no serranas de la región soriana, que solo poseían diminutos rebaños.

Entre los que contrataron con los mayores propietarios del grupo oligárquico noble destaca Diego Rodríguez de Azambújar, quien por indicios cabe presumir que les compraba sus pilas por encargo de otros portugueses con los que mantenía correspondencia. Así, en 1649 se hizo con la pila de la casa de los Río, la de mayor reputación en Soria, que como consecuencia regularmente se pagaba a razón de tres reales más por arroba que cualquier otra pila de lanas finas sorianaa ${ }^{55}$. Ese mismo año adquirió la de otro destacado señor de ganados de la villa de Ágreda, Diego Antonio de Castejón ${ }^{56}$. Y lo volvió a hacer en $1652^{57}$. Por su parte Alonso Fernández de Oporto Azambújar, el menor, en 1661 adquirió la

55 AHPS, PN, 469-814-264, Soria, 31-VII-1649.

56 AHPS, PN, 633-1062-209, Soria, 28-VI-1649.

57 AHPS, PN, 595-1013-226, Soria, 1-IX-1652. Aquí se estipuló que el pago de parte de su valor se había de efectuar con una letra sobre Fernando de Montesinos, lo que sugiere que este era el auténtico financiador de la operación. 
pila de Simón Martínez de Mendoza, alguacil mayor de la Inquisición, pagándola a un elevado precio ${ }^{58}$. En 1663 compró en compañía con Antonio Núñez Marchena, mercader residente en Ágreda, también de origen judeoconverso portugués, la de Juan de Torres y La Cerda ${ }^{59}$. Al año siguiente, en 1664, volvió a colaborar con este portugués, pues tras haber comprado por su propia cuenta las pilas de dos caballeros sorianos, Juan de Salazar y Antonio de Barnuevo, se las cedió a continuación ${ }^{60}$.

Mucho más numerosas fueron las operaciones con medianos y pequeños propietarios de las comarcas serranas sorianas que practicaban la trashumancia. Con ellos solían cerrar los contratos en el otoño o la primavera previos al esquileo, que se realizaba en junio, efectuándoles importantes adelantos de dinero. A cambio conseguían que los ganaderos aceptasen por ellas precios inferiores ${ }^{61}$. Así, en septiembre de 1635 el ganadero serrano Sebastián de Montenegro, vecino de Vinuesa, se obligó a entregar a Baltasar de Oporto 400 arrobas de lana estremeña ${ }^{62}$ de su ganado para fines de junio de 1636, recibiendo adelantado todo su valor, a razón de 15,5 reales por arroba ${ }^{63}$. Habitualmente, no obstante, las cantidades adquiridas por contrato fueron muy inferiores, porque en las comarcas serranas sorianas abundaron los dueños de pequeños rebaños que trashumaban en el invierno. Así, en octubre de 1644 otro vecino de

58 AHPS, PN, 670-1105-54, Soria, 29-I-1661. La vende a tres reales menos en arroba que el precio que obtuviese Juan de Torres y La Cerda, en quien por matrimonio había recaído la propiedad de parte de la cabaña de los Río, cuyas lanas se pagaban tres reales más caras que el resto. Recibió un anticipo de 11.000 reales de vellón.

59 Esta pila, procedente del esquileo de una fracción de la cabaña de los Río, que había tocado en los repartos sucesorios al regidor Juan de Torres y La Cerda, gozaba entonces de la máxima reputación entre las lanas finas sorianas.

60 Ambas referencias proceden del testamento otorgado por Alonso, en AHPS, PN, 707-1167-454, Soria, 29-X-1665.

${ }^{61}$ Sobre la incidencia de la concesión de crédito en las operaciones de contratación lanera en la región soriana, vid. Máximo Diago Hernando, «El crédito en el comercio lanero en la región soriana durante los siglos XVI y xVII», Revista de Historia Económica 20:2 (2002) págs. 271-299.

62 Se denomina así en los documentos la lana fina obtenida del esquileo de los ganados sorianos de raza merina que trashumaban en invierno a las dehesas del sur, para diferenciarla de la lana «churra», de los ganados estantes, y «riberiega» de los que pasaban en invierno a dehesas de Aragón y Navarra.

63 AHPS, PN, 425-747-200, Soria, 28-IX-1635. 
Vinuesa, Juan Martínez de Montenegro, se obligó a entregar en el siguiente esquileo a Baltasar de Oporto tan solo 10 arrobas de lana estre$m e \tilde{n}{ }^{64}$. Y entre ambos extremos encontramos una amplia gama de cantidades que no hay aquí lugar para detallar ${ }^{65}$.

Además de contratar directamente con medianos y pequeños señores de ganados trashumantes de comarcas serranas, los portugueses de Soria también recurrieron a comprar lanas a mercaderes intermediarios vecinos de esta ciudad o de otros núcleos del entorno. Con ellos pusieron en práctica, sin embargo, un modelo de contratación de signo radicalmente contrario. En lugar de adelantarles el dinero, se obligaban a abonarles el valor de las lanas en varios plazos tras haberlas recibido, que podían superar el año. Así, Hernando de Oporto y su mujer Francisca Rodríguez en junio de 1595, se obligaron a pagar a Juan García de Tardajos, mercader lanero de origen judeoconverso del que hablamos en otro lugar por su faceta como exportador, 6.200 reales en tres plazos que acababan en diciembre de 1596 por 400 arrobas de lana estremeña que les había vendido ${ }^{66}$. No resulta fácil determinar el destino previsto para estas lanas. Lo más probable es que la intención del comprador fuese revenderlas a mercaderes exportadores, grupo al que paradójicamente hemos demostrado que pertenecía el propio Juan García de Tardajos. Esta constatación nos da idea, pues, de hasta qué punto eran diversificadas, y hasta contradictorias, las estrategias de negociación con lanas en la Soria de aquella época.

Pero, por si esto fuera poco, los portugueses arraigados en esta ciudad no se limitaron a tratar con lanas estremeñas, de ganado trashumante. También se dedicaron con asiduidad a la compra y venta de lanas de ganado de raza churra, estante y trasterminante o riberiego, es decir el que era llevado en invierno a pastar a Aragón y Navarra. Los testimonios que la documentación notarial nos proporciona para ilustrar esta faceta de su actividad son abundantes. Por lo que respecta a las compras, que

64 AHPS, PN, 501-874-249, Soria, 7-X-1644.

${ }^{65}$ Por ejemplo, en 12-III-1644 un vecino de la aldea serrana de Torre vendió a Baltasar de Oporto 30 arrobas de lana estremeña a 19,75 reales, y en 15-IV-1644 otro vecino de Arévalo le vendió 50 arrobas a 23 reales, recibiendo en ambos casos el dinero por adelantado. AHPS, PN, 501-874-49 y 68.

66 AHPS, PN, 202-415-107, Soria, 17-VI-1595. 
regularmente efectuaban con varios meses de adelanto, anticipando todo o parte del precio, las practicaron la mayoría de los miembros de la comunidad portuguesa arraigada en Soria. Entre ellos cabe destacar a Simón de Oporto, Baltasar Méndez, su hijo Pablo Méndez, y Juan Rico. Los ganaderos que se las vendían ofrecían un perfil bastante diversificado. Hay vecinos de lugares de las comarcas no serranas de la Tierra de Soria, y de jurisdicciones próximas, como Noviercas, o de aldeas de las Tierras de Calatañazor o de Almazán. Solían obligarse a la entrega de cantidades muy pequeñas, sobre todo cuando se trataba de lana churra. En los contratos de lana riberiega la cantidad solía ser algo mayor, habida cuenta de que los rebaños de los ganaderos transterminantes eran de mayor tamaño. De otro modo no compensaba a sus dueños el negocio, que requería tomar a renta pastos en otros reinos. Entre estos ganaderos riberiegos hubo algún vecino de Soria, como el hidalgo Agustín Vallejo de Santa Cruz, que en 1597 vendió a Simón de Oporto y su mujer María Méndez cerca de 100 arrobas de lana ${ }^{67}$.

El destino que se daba por los portugueses a las lanas churras o riberiegas era también muy diverso. Una parte iría destinada a la fabricación de paños por cuenta propia, faceta de su actividad sobre la que trataremos más adelante. También abundan los testimonios de ventas efectuadas a fabricantes pañeros de las comarcas serranas ubicadas al norte de la Tierra de Soria, en las que se había desarrollado una dinámica manufactura pañera dispersa ${ }^{68}$. Hay que destacar desde este punto de vista las compras que vecinos de Enciso, efectuaron a portugueses como Juan Rico ${ }^{69} \mathrm{o}$

67 AHPS, PN, 205-422-338, Soria, 3-IX-1597. Se obligaron a pagarle 1.297 reales por 93 arrobas de lana blanca y negra a 13 reales, y 8 arrobas de lana blanca y negra y añinos, a 11 reales.

$68 \mathrm{Vid}$. Máximo Diago Hernando, «El papel de la lana en las relaciones económicas entre Soria y las villas pañeras cameranas en los siglos XVI y XVII», Berceo 138 (2000) págs. 61-90. Esta pañería rural del norte de Soria y Cameros siguió manteniendo notable vitalidad hasta el siglo XVIII, según se ha demostrado en Agustín GonzáLEz EnCISO, «La industria lanera en la provincia de Soria en el siglo XVIII», Cuadernos de Investigación Histórica 7 (1983) págs. 147-170 y «La industria dispersa en la Sierra de Cameros, 1700-1840», Cuadernos de Investigación: Historia 10 (1984) págs. 39-56.

69 Juan de Espinosa, vecino de Enciso, compró a Juan Rico 25 arrobas de lana a 16 reales; $c f$. AHPS, PN, 229-466-85, Soria, 11-IV-1616. 
Alonso de Oporto Azambújar ${ }^{70}$. En la misma línea también resulta muy reveladora una carta de poder que varios fabricantes de paños, vecinos de Viguera, otorgaron a Baltasar de Oporto para que en su nombre comprase en Soria y Tierra hasta un máximo de 400 arrobas de lana churra y riberiega del esquilo de 1628 a precios que no excediesen los fijados por la pragmática de reciente publicación ${ }^{71}$. Por otro lado también vecinos de aldeas serranas de la Tierra de Soria se contaron entre sus clientes, como el vecino de Arévalo que en 1646 compró a Juan Rico 23 arrobas de añinos churros ${ }^{72}$.

En su papel como proveedores de materia prima para los fabricantes pañeros del sector serrano de Soria-Cameros, los portugueses no se limitaron a venderles lana churra y riberiega, concediéndoles aplazamientos de pago. También les vendieron, con estas mismas condiciones, lana estremeña, de ganado trashumante, pero que no alcanzaba el nivel de calidad suficiente para ser estibada en las sacas destinadas a la exportación. Se trata de los llamados desechos de lavadero, a los que se identifica en la documentación con diferentes nombres, tales como «sacadizos», «lana de cuarto», o «tercerillo». Por ejemplo en 1650 Baltasar Rico y Alonso de Oporto, el mayor, vendieron a varios fabricantes pañeros de Yanguas 56 arrobas 8 libras de «sacadizos de lavadero» ${ }^{73}$. Conviene precisar, no obstante, que en su doble faceta de mercaderes y empresarios pañeros, estos mismos portugueses en otras ocasiones compraron deshechos a mercaderes exportadores, con frecuencia también portugueses, que habían lavado lanas en Soria ${ }^{74}$. En estos casos es muy probable

70 Varios vecinos de Enciso se obligaron conjuntamente a pagar a Alonso de Oporto Azambújar, el mayor, 2.160 reales por 60 arroba lana churra blanca y parda a 36 reales, y 7 arrobas de añinos finos azules a 100 reales; $c f$. AHPS, PN, 586-1001, Soria, 5-IX1664.

71 AHPS, PN, 489-857-62, Soria, 25-II-1628.

72 AHPS, PN, 573-984-130.

73 AHPS, PN, 576-987-430, Soria, 18-XI-1650.

74 Por ejemplo, Pablo Méndez compró sacadizos a mercaderes portugueses residentes en Valladolid, por valor de 294 reales; $c f$. AHPS, PN, 217-445-333, Soria, 17-IX1608. En otra ocasión, Baltasar Rico compró una partida de lana de «tercerillo, despojos de lavadero» al mercader soriano Juan Mateo Gutiérrez, que lavaba cada año grandes cantidades de lanas para sus correspondientes, por 660 reales; $c f$. AHPS, PN, 676-1111542, Soria, 9-VIII-1667. 
que las destinasen a la fabricación de sus propios paños, aunque tampoco se puede descartar que las revendiesen a pañeros de las comarcas serranas.

\section{LOS PORTUGUESES EN LA EXPLOTACIÓN DE LAVADEROS DURANTE EL SIGLO XVII ${ }^{75}$}

Aunque para el período medieval las fuentes documentales sorianas que han llegado hasta nosotros son muy parcas en informaciones, las pocas disponibles nos confirman que el interés que los judíos sorianos mostraron por el trato con lanas, les llevó a la adquisición de lavaderos, donde poder acondicionarlas a efectos de su posterior reventa, ya ensacadas. Así, nos consta que tras la publicación del decreto de expulsión de 1492, un hidalgo de origen santanderino asentado en Soria, Gómez de Gama, con dedicación al comercio lanero, se hizo con la propiedad de un lavadero a las orillas del Duero que compró a unos judíos que tomaron ese año el camino del exilio ${ }^{76}$.

Con posterioridad, resulta digno de notar que, en el transcurso del siglo XVI, entre los varios lavaderos que estuvieron activos en Soria a orillas del Duero, que oscilaron en torno al número de tres, hubo alguno que fue propiedad de familias identificables como de origen judío, con pruebas más o menos contundentes, como es el caso de los García de Tardajos y los Núñez.

Pero, aún llama todavía más la atención constatar que, enlazando con esta tradición secular, las familias de ascendencia judía que, procedentes de Portugal, se asentaron en Soria a finales del reinado de Felipe II, muy pronto se interesaron por la inversión en la compra de lavaderos, que luego mantuvieron en su propiedad durante todo el siglo XVII. Resulta

75 Sobre el papel de los lavaderos de lanas en la economía castellana durante la Edad Moderna, vid. Rafael María Girón PAScual, «Lana sucia, lana lavada. Los lavaderos de lana y sus propietarios en la Edad Moderna (ss. XVI-XIX). Un estado de la cuestión», Investigaciones Históricas. Época Moderna y Contemporánea 39 (2019) págs. 209-256.

${ }^{76}$ Noticia en declaraciones de testigos en AGS, EMR, Hojas e Informaciones, leg. 552 . 
paradigmático el caso de los Oporto. Así, Simón Fernández de Oporto, también identificado como Simón de Oporto Azambújar, nacido en Portugal, y que vino a vivir a Soria con sus padres Hernando de Oporto y Francisca Rodríguez, aparece como propietario de un lavadero desde los primeros años del siglo XVII. Estaba situado a orillas del Duero, encima del molino de Diego de Solier, y debajo de los lavaderos de Juan García de Tardajos, Domingo del Águila y Don Alonso Núñez. Lo cedió a renta en 1610 a su propio hermano, Alonso Fernández de Oporto, con todos sus utensilios y pertenencias por cuatro años por una renta de 1.500 reales anuales ${ }^{77}$. Este individuo mantuvo el interés por los lavaderos a lo largo de toda su vida, llegando a poseer en alguna ocasión hasta dos. Lo dice en su testamento, otorgado en el año 1645, donde confiesa que había recibido en dote con su segunda mujer un lavadero que después había vendido por 7.000 reales al mercader de origen francés Bernardino Marcel, y que continuaba siendo propietario de otro lavadero que él mismo había edificado en vida ${ }^{78}$. Este último lavadero, que permaneció en poder de sus descendientes de apellido Oporto-Azambújar a lo largo de varias generaciones, fue uno de los más activos en Soria a lo largo del siglo XVII. En 1673 fue incluido en el inventario de bienes que el hijo mayor de Simón Fernández de Oporto, Alonso de Oporto Azambújar, realizó a raíz de la muerte de su esposa, Águeda Rico ${ }^{79}$. Y en 1709 continuaba siendo propiedad de otro miembro de esta familia, Baltasar de Oporto, quien entonces declaró tener 73 años de edad y que durante gran parte de su vida se había dedicado al negocio del beneficio de la lana ${ }^{80}$. Para continuar con dicha actividad en 1686 buscó un socio, José

77 AHPS, PN, 22-453-416, Soria, 6-X-1610. Se arrendó el lavadero con su casa, lonjas, calderas, tinos, carços y pedrera.

78 Testamento de Simón Fernández de Oporto, en Soria, 10-V-1645, en AHPS, PN, 576-987-407.

79 AHPS, PN, 833-1332-64, Soria, 23-IV-1673. Lavadero en la ribera del Duero, con un «pudridero de la fábrica de añinos» al lado. En el testamento de su padre, Simón, del año 1645, este confesó que su hijo mayor Alonso le había ayudado «en los beneficios y destajos de lavadero, por ser persona que entiende y de mucha satisfacción». Por ello era su voluntad que el se quedase con el lavadero.

80 AChV, Hijosdalgo, 1531-4. Declaración de 9-IX-1709 en que hizo constar que hacía 24 años que había dejado el comercio, retirándose a mantener su persona y familia con los esquilmos de su hacienda, y que tenía un lavadero propio a orillas del Duero. 
Miguel, con el que firmó un contrato de compañía para un período de seis años. Cada uno de los socios debía asumir el pago de la mitad de los gastos, repartiéndose de igual manera por mitad los beneficios. Pero José Miguel quedaba también obligado a pagar a Baltasar de Oporto 2.000 reales de vellón cada año "por el beneficio que goza en la compañía» ${ }^{81}$.

Otro destacado mercader de origen portugués que se avecindó en Soria procedente de Palencia, Nicolás Ferraz, era propietario en 1620 de lavadero y medio en la ribera del Duero, que le fue embargado tras declararse en bancarrota ${ }^{82}$. Por este motivo dicho lavadero no se consolidó en manos portuguesas.

La familia Oporto cedió en ocasiones a renta sus lavaderos a mercaderes foráneos, habitualmente portugueses, para que lavasen en ellos sus lanas ${ }^{83}$. Pero, al mismo tiempo, sus miembros desempeñaron un papel de primera fila en el negocio del "beneficio" por cuenta ajena de enormes cantidades de lanas finas pertenecientes a otros propietarios ${ }^{84}$. Es decir, tomaron a su cargo la tarea de lavar y ensacar, a destajo, las lanas finas adquiridas en la región soriana por otros grandes mercaderes exportadores. Constituyeron para ello a veces "compañías", como la de Simón de Oporto y Juan Rico, que funcionó entre 1614 y $1616^{85}$. Por ello se les aplicó el nombre de destajeros de lavaderos.

81 AHPS, PN, 831-1330-358, Soria, 30-VII-1686.

82 AHPS, PN, 477-824-261, Soria, 29-V-1620. Inventario de bienes conocidos de Nicolás Ferraz.

83 Alonso Fernández de Oporto en nombre de su hermano Simón da a renta a Simón de Acebedo, portugués de Madrid, el lavadero con calderas, maderas y otras cosas necesarias por un año. El arrendatario debía pagar por cada sacón de 6,5 arrobas de lana limpia que hiciese 1,5 reales; $c f$. AHPS, PN, 218-446-79, Soria, 22-IV-1608.

${ }^{84}$ En 1621 Juan Rico cobró 13.652 reales de Hernán Báez de Quirós y Enrique Méndez, mercaderes portugueses de Madrid, por el destajo de 4.789 arrobas de lana, estibadas en 664 sacas; $c f$. AHPS, PN, 437-774-277. En 1651 Alonso de Oporto declaró que como «estajero» había lavado y beneficiado en su lavadero, y de sus hermanos, ese año 4.758 arrobas de lana en sucio, de las que salieron en limpio 1.877. Las lavó Diego de Luzón y Castejón, factor en Soria de mercaderes exportadores, pero no sabía para quién; cf. AHN (=Archivo Histórico Nacional), Consejos, leg. 41.339.

85 Por haber surgido discrepancias entre los dos socios sobre el reparto de los beneficios, acordaron resolverlas mediante un acuerdo amistoso; $c f$. AHPS, PN, 356-654- 
La intensa dedicación de los portugueses asentados en Soria durante el siglo XVII al negocio de los destajos de lavaderos hizo de ellos eficaces dinamizadores del mercado del trabajo estacional en esta ciudad. Esta actividad requería efectivamente la contratación de una numerosa mano de obra, con diferentes grados de especialización, que había de realizar la compleja tarea de acondicionar la lana, quitándole impurezas y lavándola con agua caliente, distribuirla por calidades o suertes y meterla en sacas. No había en la ciudad personal especializado suficiente para realizar estos trabajos. Por ello, según prueban los numerosos contratos conservados en los protocolos notariales, los destajeros recurrieron también a valerse de los servicios prestados por vecinos de otros lugares, más o menos lejanos, que acudían a ganarse el sustento durante la estación de los lavaderos, que comenzaba a finales de junio, mientras que el resto del año se dedicaban a otras actividades. De hecho la mayoría de ellos, tanto sorianos como forasteros, eran artesanos especializados del ramo textil ${ }^{86}$. Muchos procedían de las comarcas serranas ubicadas al norte de Soria en las que se desarrolló en los siglos XVI y XVII una dinámica manufactura pañera, especializada en la producción de paños de baja calidad. Se trata de vecinos de lugares como Enciso, Zarzosa, Munilla, Arnedo, San Pedro Manrique o Yanguas ${ }^{87}$. Esta compatibilización del trabajo en los lavaderos y la dedicación a la fábrica de paños el resto del año nos la ilustra un contrato firmado en 1651 por los portugueses Baltasar Rico y Alonso de Oporto con dos tejedores de paños de Soria, para que estos les tejiesen todos los paños que ellos tuviesen para fabricar durante dos años. Se incluyó en él la condición de que a ninguno de los dos se les podría impedir que durante este tiempo, si encontrasen empleo en los lavaderos a partir de San Juan, fuesen a tra-

131. Acordaron que las ganancias correspondientes al año 1614 se repartiesen por mitad, y las de 1615 a razón de dos tercios para Juan Rico, y un tercio para Simón.

${ }^{86}$ Un batanero se obliga a servir en el lavadero del portugués, como traslavador o como capitán del río, por 8 ducados mensuales si fuese traslavador, o por 10 mensuales si fuese capitán; $c f$. AHPS, PN, 495-867-61, Soria, 21-III-1632. Un tejedor de lienzos servirá en el oficio de apartar lanas en el siguiente verano por un salario de 6 ducados mensuales, más comida y bebida; $c f$. AHPS, PN, 608-1032-79, Soria, 8-III-1640. Un tejedor de paños se obliga en 1625 a servir en el oficio de lavador por 55 reales cada mes de 30 días, más comida y bebida; $c f$. AHPS, PN. 382-691-120.

87 Cf. nota 68 supra. 
bajar donde se les ofreciese, interrumpiendo temporalmente sus labores como tejedores ${ }^{88}$.

Debido a la enorme demanda de trabajo estacional que los lavaderos generaron en Soria a partir de finales de junio de cada año acudieron a trabajar en ellos incluso personas procedentes de comarcas muy distantes, como la Cornisa Cantábrica, aparentemente especializada en aportar estibadores. Así, en 1648 los hermanos Baltasar y Alonso de Oporto contrataron para que sirviese como estibador en sus lavaderos a un vecino del Valle de Piélagos, en tierras santanderinas ${ }^{89}$. En 1643 cuatro vecinos de este mismo valle se obligaron a servir como estibadores de lana en los lavaderos que tuviesen ese año en Soria el francés Bernardino Marcel y el portugués Simón de Oporto ${ }^{90}$. Por otro lado también acudieron a Soria a trabajar en los lavaderos vecinos del ducado de Medinaceli, pese a que allí también había lavaderos de lanas, entre los que destacan los de Luzón y Anguita ${ }^{91}$.

Los protocolos notariales sorianos del siglo XVII rebosan de contratos firmados por miembros de las familias Oporto-Azambújar, Méndez, Rodríguez y Rico, con frecuencia emparentados entre sí, con individuos que, a cambio de recibir un pequeño adelanto de dinero, se obligaban a servirles en las tareas de lavadero que habrían de iniciarse en el siguiente mes de junio. En el inventario de bienes de Alonso de Oporto realizado a raíz de la muerte de su mujer Águeda Rico, se alude a un «libro de señales», y se reconoce que en aquellos momentos estaban entregados adelantos o señales para que sirviesen en el próximo lavadero a once vecinos de Soria, uno de Almazán, y doce de Enciso, que recibieron en total 2.042 reales, aunque las cantidades entregadas a cada uno fueron muy variables ${ }^{92}$.

88 AHPS, PN, 577-988-83, Soria, 26-II-1651.

89 AHPS, PN, 575-986-309, Soria, 22-VIII-1648. Un vecino de Puente de Arcia, del valle de Piélagos, se obliga a trabajar en los lavaderos de 1649, en el oficio de estibador, cobrando 54 mrs. por cada sacón de 7 arrobas.

90 AHPS, PN, 570-981-280, Soria, 17-VI-1643.

91 Simón Fernández de Oporto contrató en 1645 a dos vecinos de Luzón y tres de Anguita para servir en sus lavaderos de 1646, pagándoles 85 reales a cada uno por mes, y de comer, y "por la venida a Soria» dos reales a cada uno y un día de salario; $c f$. AHPS, PN, 501-874-672, Soria, 27-VIII-1645.

92 AHPS, PN, 833-1332-64, Soria, 9-V-1673. 
8. LOS PORTUGUESES COMO EMPRESARIOS PAÑEROS DURANTE EL SIGLO XVII

Al igual que en el conjunto de la Corona de Castilla, la manufactura pañera en la ciudad de Soria no consigue recuperar durante el siglo XVII el grado de desarrollo logrado en las décadas centrales del siglo XVI, tras el retroceso experimentado en las últimas décadas de esta centuria. Pese a ello continuó siendo una de las actividades económicas fundamentales de la ciudad, y la que mayor número de puestos de trabajo garantizaba a la población local. Las familias judeoconversas procedentes de Portugal que se asentaron en las últimas décadas del siglo XVI realizaron una contribución fundamental al mantenimiento de esta actividad durante el siglo XVII. Son muchos los indicios que proporciona la documentación que confirman que varios de los principales empresarios del sector pañero en Soria pertenecieron en este período a dichas familias.

Tenemos noticia sobre la inversión por estos portugueses de capital en empresas pañeras. Así, en 1606 Simón Fernández de Oporto Azambújar confesó que, en virtud del último ajuste de cuentas, adeudaba a su cuñado Diego Rodríguez, vecino entonces de Soria, 4.904 reales por dineros que le había entregado «para acabar unos paños que fabricaba en Soria» ${ }^{93}$.

Por otro lado abundan los contratos de adquisición por su parte de materias primas básicas para la fábrica de paños. Compraron importantes cantidades de sacadizos procedentes de los lavaderos de lanas finas. Así, Pablo Méndez los compró a mercaderes portugueses de Valladolid, por valor de 294 reales, en $1608^{94}$. En 1667 Baltasar Rico compró al mercader soriano Juan Mateo Gutiérrez una partida de lana de tercerillo de «despojos de lavadero» ${ }^{95}$.

En segundo lugar también realizaron con frecuencia compras de tierra de Magán o de los cerros de Madrid, para las labores de batán, según ilustran contratos firmados por Baltasar Méndez en 1585 y $1586^{96}$, o por

\footnotetext{
93 AHPS, PN, 100-223-258, Soria, 18-VII-1606.

94 AHPS, PN, 217-445-333, Soria, 17-IX-1608.

95 AHPS, PN, 676-1111-542, 9-VIII-1667.

96 AHPS, PN, 83-189 y 54-127.
} 
su hijo Pablo Méndez en $1619^{97}$. Por otro lado, se concertaron con bataneros para que les adobasen sus paños, según testimonia un contrato de Simón Fernández de Oporto del año $1610^{98}$. No consta, sin embargo, que llegasen a ser propietarios de batanes, por tratarse de una infraestructura de elevado precio que no solía formar parte de los patrimonios de los mercaderes, sino más bien de los de las familias de la oligarquía de caballeros. Pero, en contrapartida, sí que invirtieron en la adquisición de tintes, mucho más asequibles. Así, Juan Rico en su testamento de 1642 declaró que había donado a su hijo Martín un tinte que previamente había comprado de los testamentarios de Ana Carrasco por 500 duca$\operatorname{dos}{ }^{99}$.

Los procedimientos a los que recurrieron para promover la fabricación de paños debieron estar muy diversificados, pero la documentación consultada no permite conocerlos con el deseable detalle. Destaca la contratación de artesanos especializados para que les tejiesen paños en régimen de exclusividad durante un determinado período de tiempo. Así, en 1648 Baltasar Rico se concertó con Domingo Ibáñez, tejedor de paños vecino de Soria, para que le tejiese todos los paños que él tuviese para fabricar en su obrador en Soria durante un año, a partir del día de San Juan. Le habría de pagar por los dieciochenos, frailengos y mezclas a razón de 26 reales por paño, y por los veintidosenos a razón de 36 reales ${ }^{100}$. En estos contratos era habitual que efectuasen adelantos de dinero a los tejedores. A veces incluso les proporcionaban un telar para poder trabajar en él, lo que nos da idea de hasta qué punto estos artesanos desarrollaban su labor en condiciones de precariedad y fuerte dependencia frente al empresario dueño del paño ${ }^{101}$.

\footnotetext{
97 AHPS, PN 234-475-19.
}

98 AHPS, PN, 220-450-3, Soria, 4-I-1610.

99 AHPS, PN, 569-980-540, Soria, 12-XII-1642.

100 AHPS, PN, 575-986-210, Soria, 16-VI-1648.

101 En el ya mencionado contrato de Soria, 26-II-1651, firmado por Baltasar Rico y Alonso de Oporto, el mayor, con dos tejedores de paños de Soria, para que les tejiesen paños durante dos años, se hizo constar que les prestaban un telar con su peine dieciocheno. La remuneración por paño es la misma que en otros contratos, 26 reales por paño dieciocheno, y 36 reales por veintidoseno; $c f$. AHPS, PN, 577-988-83. 
Escasas son las noticias reunidas sobre la comercialización de los paños fabricados. Sabemos que les daban salida en ferias. Así el mercader Baltasar Méndez en su testamento del año 1591 declaró que había entregado a Juan Gil, mercader vecino de Soria, cuatro paños frailengos y uno salmonado para que se los vendiese en la feria y a su sobrino le había entregado dos paños salmonados para que los llevase a vender, si bien, por no haber logrado venderlos, los había dejado en la ciudad de Burgos ${ }^{102}$. Por otro lado, tenemos noticia de ventas de paños efectuadas a vecinos de Logroño por Simón Fernández de Oporto en $1609{ }^{103}$.

\section{INVERSIÓN EN LA EXPLOTACIÓN DE GANADOS}

Entre la amplia gama de actividades económicas en las que invirtieron las familias de origen judeoconverso portugués arraigadas en Soria, figuró también la explotación de ganados. Pero se trató de inversiones de carácter muy modesto, debiéndose destacar que no se tiene constancia de que ninguno de ellos llegase a poseer una cabaña de ganado de lana fina, trashumante, que era la que mejores perspectivas de beneficio ofrecía en Soria en estos siglos, por la fuerte demanda de tal tipo de lana existente en los mercados internacionales.

Entre los portugueses que invirtieron en la actividad ganadera figura uno con negocios muy diversificados y ambiciosos, pero que arriesgó demasiado y al final de su vida se tuvo que declarar en quiebra, acosado por sus acreedores. Se trata de Nicolás Ferraz, quien solicitó la vecindad en Soria en $1610^{104}$, pero que con anterioridad había sido vecino de Palencia, y también tuvo conexiones con otras ciudades como Valladolid o San Sebastián, donde residían cuñados suyos con los que realizó negocios en compañía. Él mismo, después de 1610, se ausentó con frecuencia de la ciudad del Duero dejando en manos de

102 El testamento se encuentra en AHPS, PN, 197-401-85, Soria, 26-XII-1591.

103 AHPS, PN, 323-615-226.

104 AHPS, PN, 141-296-180. Soria, 22-IX-1610. Nicolás Ferraz declara que el concejo de Soria le admitió como vecino. Ofrece como fiador al mercader soriano Juan de Ayuso. 
su mujer la gestión de sus negocios en la misma ${ }^{105}$. Pese a esta propensión a la movilidad, característica de muchos de los miembros de la "nación portuguesa" en aquella época, Nicolás Ferraz fue de los pocos miembros de esta "nación" que invirtió en la explotación de ganado, aunque lo hizo a una modesta escala y con escasa fortuna. Según un inventario de su hacienda que se realizó en 1620, cuando ya se había declarado en quiebra, poseía en aquellos momentos un rebaño de en torno a 600 cabezas de ganado ovino que inicialmente había rondado el millar ${ }^{106}$. No se trataba, sin embargo, de ganados de lana fina sino de los llamados riberiegos o trasterminantes, que en invierno eran llevados a pastar a Aragón, y producían lana de inferior calidad y precio $^{107}$.

Menor relevancia incluso tuvieron como ganaderos los demás portugueses arraigados en Soria para los que hemos localizado referencias documentales. Es el caso de Juan Rico, quien en 1605 contrató a un vecino de la aldea soriana de Izana, para guardar su ganado lanío y cabrío por un año, desde San Pedro ${ }^{108}$. Por su parte el licenciado Manuel Porto de Azambújar, vicario de la iglesia parroquial de Lubia, aldea de la Tierra de Soria, en su testamento del año 1702 confesó ser propietario de «un pedazo de ganado lanío de hasta 800 cabezas de carneros y ovejas», y 600 de ganado cabrío ${ }^{109}$.

105 Cuando al final de su vida se declaró en quiebra, se encontraba en Valladolid, donde buscó asilo frente al acoso de sus acreedores en el monasterio de San Basilio, extramuros de dicha ciudad. Allí otorgó poder a su esposa en 25-IV-1619, según se recoge en AHPS, PN, 476-823-27.

106 AHPS, PN, 477-824-262, Soria, 29-V-1620. El rebaño había quedado reducido a 419 cabezas de lana, 182 borregos y 12 ovejas viejas, cuando la viuda de Nicolás Ferraz, en Soria, 19-VIII-1621, lo puso a la venta en público pregón; $c f$. AHPS, PN, 447-825-179.

107 En Soria, 10-XII-1620, un pastor vecino de Portillo, confesó haber recibido de Isabel Pereira, mujer de Nicolás Ferraz, 538 cabezas de ganado (10 cabras y el resto ovejas), para llevar al reino de Aragón; $c f$. AHPS, PN, 477-824-122. Con anterioridad Isabel Pereira había otorgado poder para tomar a renta pastos en el reino de Aragón; $c f$. AHPS, PN, 229-467-229, Soria, 31-VIII-1618.

108 AHPS, PN, 214-439-115, Soria, 16-VI-1605.

$109 \mathrm{Su}$ testamento se encuentra en AHPS, PN, 934-1455-173, Soria, 12-VIII-1702. 


\section{El COMERCIO DE TEJIDOS DE IMPORTACIÓN}

Las familias portuguesas arraigadas en Soria a fines del siglo XVI desplegaron una intensa actividad en el negocio de la venta de tejidos que no eran de su propia producción, sino importados, todos ellos de una calidad y precio muy superiores a los de la manufactura local. De este modo dieron continuidad a una actividad en la que ya habían despuntado judíos sorianos desde el siglo xIV, y más adelante varios judeoconversos en el transcurso de los siglos XV y XVI.

Grandes cantidades de tejidos entraron en la Corona de Castilla a través de Navarra, procedentes de Francia y otros países europeos. No sorprende por tanto que los portugueses afincados en Soria tuviesen intensos tratos con mercaderes navarros ${ }^{110}$. Así, a fines del siglo XVI, Hernando de Oporto y su hijo Simón, estuvieron en frecuente contacto con el mercader Martín Francés, vecino de Tudela, que utilizaba como factor en Castilla a un vecino de Ágreda, Juan Ruiz de Villoslada. Le compraron tejidos de importación y productos de mercería de una muy variada gama ${ }^{111}$. También negociaron con otro destacado mercader de esta misma ciudad navarra, Juan de Navascués, a quien compraron en 1601 una variada gama de tejidos y productos de mercería, por valor de cerca de 10.000 reales de plata, que se obligaron a hacerle efectivos en varios plazos en la villa fronteriza de Ágreda ${ }^{112}$. La importancia que los

110 Sobre el papel de los mercaderes navarros en el comercio internacional en el siglo Xvi, vid. Valentín VázQuez de Prada Vallejo, Mercaderes navarros en Europa. Siglo XVI (Pamplona: Gobierno de Navarra, 2015).

111 Hernando y Simón de Oporto se obligaron a pagar a Martín Francés, 4.798 reales en dos plazos por navales, fustanes, anascotes, melunges y resmas de papel que le habían comprado; $c f$. AHPS, PN, 258-527-328, Soria, 14-X-1598. A los pocos días, Hernando de Oporto se obligó a pagarle 1.160 reales por el valor de unas piezas de Olanda y otros productos de mercería; $c f$. AHPS, PN, 258-527-359, Soria, 22-XI-1598.

112 AChV, RE, 1953-91 (19-IV-1603). Ejecutoria del pleito entre Juan de Navascués, y Hernando de Oporto, su mujer Francisca Rodríguez, su hijo Simón de Oporto, y la esposa de este, María Méndez. Por contrato de obligación otorgado en Soria, 15-III-1601 estos cuatro se había obligado a pagar al de Tudela 9.975 reales por razón de las siguientes mercancías: 250,5 varas de olandas blancas, 48 varas de olandas curadas, 8 piezas de lilas negras anchas a 11,5 ducados cada una; 11 piezas de bocarenes; 12 piezas de telillas de jubones; dos piezas de ruanes; un fardel de brienes anchos, un fardel de $n a-$ vales; 5 mazos de hilo y 4 piezas de lilas estrechas de colores. 
tejidos de importación tuvieron en los negocios de Hernando de Oporto queda corroborada por el inventario de su tienda, que su viuda Francisca Rodríguez realizó tras su muerte en 1605 . En él se mencionan muy diversos tejidos, productos de mercería, algodón y sedas, pero también una amplia gama de otro género de productos, como papel, confitura, mermelada, azúcar, especias, pasas, ciruelas, avellanas, cera, alpargatas, miel, vinagre, garbanzos, lentejas, jabón o hierro ${ }^{113}$.

Otra vía por la que se surtieron de tejidos de importación para redistribuirlos en el mercado castellano fue mediante su adquisición en los puertos del Cantábrico. Así, como ya hemos avanzado, Pablo Méndez, vendió en 1610 en San Sebastián 80 sacones de lana a un mercader francés, que le entregó enpago 36 piezas de fustanes de Lyon, 9 piezas de Lilas, 5 piezas de anascotes, 4 piezas de chamelotes, 840 libras de almidón, 154 libras de trenzaderas y 6 piezas de bayetas ${ }^{114}$. Por su parte, el testamento de Alonso de Oporto de 1665 aporta noticias sobre compras de paños que él había realizado en esta misma villa guipuzcoana en compañía con el mercader soriano Juan Mateo Gutiérrez ${ }^{115}$, los cuales se remitieron para su venta a un mercader de Madrid llamado Juan Romero.

Otro producto que habitualmente estuvo asociado con los textiles y mercería de importación en los negocios de los mercaderes que operaron a gran escala en la Corona de Castilla durante el siglo XvII fue la cera, para la que existía entonces una enorme demanda, en especial para usos litúrgicos. Los mercaderes portugueses arraigados en Soria también se interesaron por el trato con este producto. Así, Baltasar de Oporto Azambújar, el menor, hijo del mercader homónimo y sobrino de Alonso de Oporto Azambújar, confesó en su testamento de 1661 que «toda la hacienda que tengo consiste en la cera y cosas de mi tienda, cuatro novillos y alhajas de entrecasa», junto con muchas cantidades de dinero que se le adeudaban por mercancías sacadas de su tienda. La cera es probable

113 AHPS, PN, 294-578-44, Soria, 14-XI-1605.

114 AHPS, PN,324-616-102.

115 Sobre la importancia de este mercader soriano, al que no se le conocen orígenes judeoconversos, vid. Máximo Diago Hernando, «Comercio y finanzas en una ciudad castellana de la segunda mitad del siglo XVII: Los negocios de Juan Mateo Gutiérrez en Soria», Hispania 228 (2008) págs. 63-106. 
que fuese de importación, pues había mantenido relaciones comerciales y financieras con vecinos de Bilbao y San Sebastián ${ }^{116}$. En este mismo puerto guipuzcoano se abasteció de este producto Alonso de Oporto, quien en su testamento de 1665 confesó que debía a un mercader flamenco allí residente 6.000 reales de plata «de una partida de cera que me dio, la cual tengo en mi casa por no ser buena» ${ }^{117}$.

\section{Otras ACTIVIDADES MANUFACTURERAS: El tRABAJO DEL CUERO}

Como solía ocurrir en la mayoría de las ciudades de la Europa bajomedieval, tras la manufactura textil, la del trabajo del cuero era la que seguía en orden de importancia entre las del sector secundario. Soria no fue ninguna excepción. Y resulta digno de notar que los portugueses arraigados en esta ciudad en las décadas finales del siglo XVI, en su afán por diversificar sus inversiones, también mostraron fuerte interés por esta actividad. En primer lugar invirtieron en la compra de tenerías desde fecha muy temprana, tras su avecindamiento en Soria. En 1601 Hernando de Oporto y su hijo primogénito Simón de Oporto ya eran propietarios de al menos dos, ubicadas debajo de los lavaderos de lanas en la ribera del Duero ${ }^{118}$.

Otros portugueses como Baltasar Méndez, y varios miembros de su familia figuran entre los más activos tratantes con cueros en Soria a fines del XVI y comienzos del XVII. Según el testamento del primero, otorgado en 1591, había sido miembro de la cofradía de San Juan de los pellejeros. $\mathrm{Y}$ en los protocolos notariales abundan los contratos de adquisición por los diferentes miembros de la familia Méndez de colambre de carnicerías, concertados con los más diversos proveedores, desde vecinos de pequeñas aldeas como Villabuena o Hinojosa del Campo, hasta otros

116 AHPS, PN, 733-1195-270.

117 AHPS, PN, 707-1167-454, Soria, 29-X-1665.

118 Las hipotecaron en un contrato de obligación suscrito con mercaderes navarros, al que ya hemos hecho referencia. Se inserta el contrato en AChV, RE, 1953-91. Una de dichas tenerías la acababan de comprar a Juan de Salazar, el mayor, y Francisco de Salazar, su hijo, vecinos de Soria, por un precio de 500 reales; $c f$. AHPS, PN, 259-528308, Soria, 8-X-1600. 
de lugares más poblados, como Almazán o la propia ciudad de Soria, el mayor centro de consumo de carne de la región ${ }^{119}$. Respecto a la salida que dieron a la mercancía cabe recordar que Juan Méndez, hermano de Baltasar, efectuó envíos a Sevilla, donde existía fuerte demanda de cuero, producto fundamental para el embalaje del azogue que se embarcaba allí con destino a América ${ }^{120}$. Contemporáneo de los Oporto y los Méndez fue Diego López Baldresero, quien despunta a juzgar por la documentación conservada como el empresario del cuero con mayor volumen de negocio en Soria en el tránsito entre los siglos XVI y XVII. Por indicios también sospechamos que era de origen portugués, aunque no hemos encontrado pruebas concluyentes para demostrarlo.

\section{OtROS NEGOCIOS}

Los judeoconversos de origen portugués residentes en Soria durante el siglo XVII no solo despuntaron por la diversidad de sus inversiones en actividades mercantiles y manufactureras. En su afán por diversificar, también dedicaron atención a los negocios financieros del más diverso signo. En primer lugar los encontramos con frecuencia desempeñando funciones relacionadas con la recaudación de impuestos debidos a la Real Hacienda. Nos limitaremos a ilustrar esta faceta de su perfil proporcionando unos pocos datos, sin pretensiones de exhaustividad. Así, los encontramos como administradores de los estancos de productos de origen colonial que se distribuían en régimen de monopolio. En concreto Baltasar de Oporto Azambújar fue administrador del estanco del tabaco

119 En Soria, 12-X-1601. Francisco García, mercader, Juan Méndez y su hijo Lucas Méndez se obligaron a pagar a Domingo del Águila 1.663,5 reales, por razón de 1.109 pellejos de las carnicerías de Soria caídos desde 24-VI-1601 hasta 11-X. También se obligaron a adquirirle los que se obtuviesen en delante de las reses sacrificadas para dichas carnicerías, al mismo precio de 1,5 reales cada uno; $c f$. AHPS, PN. 317-605-23.

120 Contrato con unos arrieros de San Andrés, aldea de Soria, para transportar a Sevilla por cuenta de Diego López, mercader, 112 docenas de baldrés, y de Juan Méndez 256 docenas de baldrés para entregar a Martín de Urozperueta, administrador de la paga del azogue de las Indias por el rey; $c f$. AHPS, PN, 257-526-354, Soria, 25-V-1594. En Soria, 26-X-1589 Juan Méndez, el mayor, otorgó poder a su hijo Marco Méndez, para cobrar de Alonso de Merlo, jurado de Sevilla, el dinero que le debía por razón de baldrés y otras mercancías que le había vendido; $c f$. AHPS, PN, 242-484-116. 
de Soria y su partido, por seis años, desde 1654 hasta $1660^{121}$. Francisco Fernández de Oporto tuvo a su cargo las rentas de la pimienta y de la goma de la ciudad de Soria, por delegación de Francisco de Acosta, vecino de Madrid, hasta su muerte, sucediéndole en la administración su viuda María de Burgos ${ }^{122}$.

También tuvieron a su cargo con frecuencia la tesorería de diversos impuestos debidos a la Real Hacienda. Sin duda el desempeño de esta función les fue facilitado por las estrechas conexiones que mantenían con los grandes financieros, preferentemente judeoconversos portugueses, que concertaban asientos con la Monarquía, a los que desde Soria servían como agentes para sus contrataciones laneras, pues muchos de estos asentistas fueron destacados exportadores de lanas finas ${ }^{123}$. Francisco Fernández de Oporto fue nombrado receptor de millones de Soria y provincia en 1632 por 14 meses, y de nuevo en $1634^{124}$. En 1631 ya ejercía como tesorero de alcabalas, tercias, martiniegas y otras rentas del concejo de Soria ${ }^{125}$, y en 1634 se le designó como receptor general del servicio de los 800.000 ducados ${ }^{126}$. Por su parte, Alonso de Oporto, según hizo constar en su testamento de 1665, fue depositario del servicio ordinario y extraordinario de Soria y su provincia desde 1654 hasta 1659 , y depositario de los unos por ciento de Soria y provincia de 1664 y 1665. Baltasar Fernández de Oporto en 1650 era tesorero de millones de So-

121 AHPM, 8058-1066, Madrid, 23-XI-1653. No obstante, ya en 1651 Baltasar de Oporto desempeñaba el oficio de estanquero del tabaco de Soria, por el que se le cargó un impuesto de 110 reales; $c f$. AHPS, PN, 601-1021-96.

122 En Madrid, 13-VII-1639 Francisco de Acosta otorgó carta de pago a María de Burgos, viuda de Francisco de Oporto, tras haber ajustado cuentas; $c f$. AHPM, 5666-345. La cuenta del estanco ajustada en Soria, 4-VII-1638, se encuentra en AHPS, PN, 565976-330.

123 Ángel García SAnz («Crédito, comercio y exportación de lana merina», en Dinero, moneda y crédito en la monarquía hispánica, ed. Antonio M. Bernal [Madrid: Marcial Pons, 2000] págs. 495-510) propone una interesante hipótesis sobre la conexión entre asientos y exportación de lanas.

124 Actas del concejo de Soria de 23-VIII-1632 y 3-I-1634.

125 Según el acta de concejo de Soria de 13-I-1631, la ciudad acordó que prosiguiese en el ejercicio de dicho oficio.

126 Consta por acta de sesión de concejo de Soria de 19-VI-1634. 
ria ${ }^{127}$. Y Diego Rodríguez de Azambújar actuaba en 1644 como receptor del alfolí real de esta misma ciudad ${ }^{128}$.

Otra actividad por la que se interesaron fue la administración de haciendas pertenecientes a antiguas familias de la oligarquía caballeresca que habían recaído por los avatares de las sucesiones en propietarios absentistas. Así, Pablo Méndez fue nombrado por Suero de Vega, vecino de Palencia en quien había recaído la propiedad del mayorazgo de los Beteta, tenentes de la fortaleza de Soria en los siglos XV y XVI, como administrador de sus rentas en Soria y su partido. Para ello tuvo que ofrecer fianzas por valor de 4.000 ducados, y presentó como fiadores a Juan Rico y Simón Fernández de Oporto, ambos de origen judeoconverso portugués ${ }^{129}$.

Relacionada con la administración de haciendas de grandes propietarios absentistas estuvo la recaudación de rentas de miembros del clero, puesto que ambas actividades les abrieron el camino para la activa participación en el mercado del cereal. Baltasar Méndez en su testamento de 1591 declaró que tenía arrendados varios préstamos, uno de ellos perteneciente al canónigo Soto ${ }^{130}$. Por su parte Alonso de Oporto, hermano del prior de la colegiata de Soria, en su testamento del año 1665 declaró que tenía arrendadas las canonjías pertenecientes al deán de dicha colegiata, por cuatro años ${ }^{131}$.

Por fin también realizaron incursiones en el negocio de los préstamos, que les puso en contacto con una clientela de muy variado perfil socioeconómico. Así, por un lado, en su testamento de 1656 Diego Rodríguez de Azambújar declaró haber prestado dinero a varios miembros de familias de la oligarquía soriana ${ }^{132}$. En 1676 el caballero Alonso de Sotomayor y su mujer recibieron prestados de Francisco Fernández Porto y

127 Como tal efectúa pagos a César Ayroldo, factor del rey, por libranzas; $c f$. AHPM, 6526-945 y 1443 .

128 AHPS, PN, 501-874-6.

129 AHPS, PN, 290-572-123, Soria, 17-VI-1621.

130 AHPS, PN, 197-401-85, Soria, 26-XII-1591.

131 AHPS, PN, 707-1167-454, Soria, 29-X-1665.

132 Isabel Altamirano, mujer de Cosme de Salcedo, le debía 1.600 reales y 12 doblones. Antonio de Barrionuevo 400 reales, Lorenzo de Salazar dos doblones, y Rodrigo de Salcedo y Camargo 1.900 reales; cf. AHPS, PN, 581-993-318, Soria, 31-V-1656. 
Escalante, canónigo de San Pedro, y de su hermano Alonso, 2.700 reales «para gastos urgentes» ${ }^{133}$. Pero en el otro extremo de la jerarquía social también encontramos a miembros del campesinado que recibieron préstamos para atender sus necesidades en el difícil período anterior a la recogida de la cosecha ${ }^{134}$.

\section{INDICIOS DE INTEGRACIÓN EN LA SOCIEDAD SORIANA DEL SIGLO XVII}

Del gran número de portugueses que pasaron por Soria, o tuvieron allí intereses mercantiles por razón de las lanas, a partir del reinado de Felipe II, solo un grupo relativamente reducido arraigó en la ciudad del Duero. Ha sido exclusivamente a este grupo al que hemos dedicado nuestra atención en el presente trabajo, centrado en poner de manifiesto que estos individuos desempeñaron un papel fundamental en la promoción de actividades económicas en las que en los siglos precedentes habían despuntado numerosos judíos y judeoconversos residentes en la ciudad del Duero. Todos ellos contribuyeron de forma decisiva al reforzamiento de la "clase media" local, que era bastante débil.

Los portugueses que se asentaron en Soria a finales del reinado de Felipe II tendieron efectivamente a incorporarse a dicha "clase media", $\mathrm{y}$, aunque algunos alimentaron pretensiones de hidalguía, fue en el seno del Común de pecheros donde se movieron con más comodidad, ocupando posiciones dirigentes. No encontramos entre ellos casos de ascenso e integración en el grupo oligárquico noble como los que habían protagonizado en los siglos XV y XVI varias familias judeoconversas. Pero, sin alcanzar estas cotas de éxito en su promoción, no les estuvieron vedados ciertos logros en el proceso de su integración en la sociedad local, aunque fuese solo para ocupar un escalafón inferior al de la oligarquía de caballeros.

133 AHPS, PN, 718-1178-326, Soria, 24-XI-1676.

134 En 1648 varios vecinos de aldeas de Tierra de Calatañazor reciben prestados de Diego Rodríguez Azambújar 550 reales, y un vecino de Tapiuela 144 reales; $c f$. AHPS, PN, 691-1150, Soria, 23-I-1648 y 30-V-1648. 
La misma tendencia se observa en lo que toca a las carreras de los miembros que destinaron a la Iglesia. Como ya había ocurrido en siglos anteriores, los beneficios eclesiásticos no estuvieron vetados para estos descendientes de judíos, que en muchos casos mantenían estrechas relaciones de negocios con otros miembros de su "nación" residentes en ciudades francesas u holandesas que de forma más o menos abierta practicaban el judaísmo, o se inclinaban hacia el agnosticismo o incluso el ateísmo. Escalaron a las principales posiciones en el seno de la iglesia local, aunque no nos consta que ninguno accediese al cabildo de la catedral, que tenía su sede en la villa de Burgo de Osma. En el cabildo de la colegiata de San Pedro de Soria sí lograron, sin embargo, hacerse un hueco. En concreto Francisco Fernández de Oporto Azambújar, hermano del mercader Alonso, era prior de dicho cabildo cuando otorgó su testamento en $1675^{135}$. Su hermano Gregorio de Oporto, compartió con él asiento en el mismo cabildo como canónigo ${ }^{136}$. También fue canónigo de San Pedro Francisco Fernández Porto y Escalante, hijo de Alonso Fernández Porto y María Martínez de Escalante ${ }^{137}$. En un escalafón inferior dentro de este mismo cabildo encontramos a Juan Rico, hijo del mercader Juan Rico y de Francisca Méndez, quien no pasó de simple racionero, pese a sus estudios en la Universidad de Alcalá ${ }^{138}$. Por su parte, el licenciado Manuel de Oporto tuvo que conformarse con una posición aún más modesta, la vicaría de la iglesia parroquial de la aldea de Lubia, que ocupaba en $1682^{139}$. En conjunto se trata de beneficios eclesiásticos modestos, sobre todo si comparamos con los que lograron los judeconversos sorianos en los siglos XV y XVI, de familias como los Ramírez de Lucena, San Clemente y Beltrán ${ }^{140}$. No cabe duda de que

135 AHPS, PN, 717-1177-638, Soria, 16-II-1675.

136 Consta por el testamento de la madre de ambos, María de Burgos; $c f$. AHPS, PN, 587-1003-280, Soria, 22-XI-1668.

137 AHPS, PN, 718-1178-326, Soria, 24-XI-1676.

$138 \mathrm{Su}$ padre, el mercader Juan Rico, en su testamento declara que había gastado con él 500 ducados, en sus estudios de gramática en el colegio de la Compañía de Jesús y en la Universidad de Alcalá, «y en las bulas de la ración que tiene en San Pedro, y las de los dos beneficios simples que tiene»; $c f$. AHPS, PN, 569-980-540, Soria, 12-XII1642.

139 AHPS, PN, 826-1324-133.

140 Vid. Diago Hernando, «Luces y sombras en el proceso...». 
las oportunidades de promoción en la Iglesia para los judeoconversos se habían reducido en el siglo XVII, al menos en el ámbito soriano, pero seguía sin exigírseles en la práctica la tan cacareada "pureza de sangre" ${ }^{141}$.

Además de encontrar acomodo para algunos de sus miembros en las instituciones eclesiásticas sorianas, los portugueses que arraigaron en esta ciudad durante el siglo XVII también hicieron ostentación de pública adhesión a las prácticas devocionales del catolicismo contrarreformista. Cabe destacar desde este punto de vista su incorporación activa a las cofradías. Alonso de Oporto fue preboste de la del Dulce Nombre de Jesús y Nuestra Señora del Rosario. Simón de Oporto Azambújar fue preboste de la del Mirón, una de las más antiguas y prestigiosas de Soria. Y tanto él como su hijo Alonso lo fueron además de la del Santísimo Sacramento, radicada en la iglesia parroquial del Espino. De este misma cofradía fue preboste Diego Rodríguez de Azambújar, según confiesa en su testamento de 1656.

Otra cofradía que tenía su sede en esta misma iglesia del Espino, la de las Ánimas del Purgatorio, atrajo la devoción de los portugueses. Lo prueba que Alonso Fernández Porto de Azambújar y Águeda Rico, su mujer, por su testamento otorgado el 12 de marzo de 1672, le legaron dos casas de su propiedad en la cuadrilla de Santa Catalina y una viña en uno de los pagos de la ciudad. A cambio la cofradía quedaba obligada a celebrar por sus ánimas dos memorias con dos aniversarios en la iglesia del Espino, en las fiestas de San Ildefonso y de Santa Águeda ${ }^{142}$. A título de anécdota, que puede no estar exenta de cierto significado, cabe recordar que esta iglesia parroquial, que subsiste como tal en la actualidad, se ubicaba en pleno barrio donde tras 1492 residieron la mayoría de los judíos que permanecieron en Soria tras su conversión al cristianismo ${ }^{143}$.

141 Entre la abundante bibliografía que aborda la controvertida cuestión de los estatutos de limpieza de sangre puede consultarse Albert Sicroff, Los estatutos de limpieza de sangre (Madrid: Taurus, 1985).

142 AHPS, PN, 718-1178-304.

143 Vid. Diago Hernando, «Los judeoconversos en Soria después de 1492», págs. 263-271. 


\section{Conclusiones}

La realización de monografías de carácter local está justificada desde el punto de vista metodológico porque permite profundizar en el tratamiento del material documental que nos pone en contacto más directo con la realidad empírica, para en una segunda fase estar en condiciones de someter a prueba con mayores garantías las hipótesis explicativas de los procesos históricos. De este modo se evitan los riesgos que conlleva adoptar un procedimiento eminentemente deductivo, que nos puede llevar a perdernos por los peligrosos terrenos de la especulación, cuando no en el de los prejuicios, a veces de pura raíz ideológica.

Para valorar mejor el papel que las minorías judía y judeoconversa jugaron en la economía y la sociedad de la Corona de Castilla durante los períodos medieval y moderno, y escapar de fáciles generalizaciones no sometidas a comprobación, resulta imprescindible continuar realizando este tipo de trabajos. Desde este convencimiento hemos abordado la redacción del presente artículo, que en parte es síntesis de los resultados de otros anteriores, y en parte se basa en el análisis de un abundante cuerpo documental inédito correspondiente a los siglos XVI y XVII. Hemos escogido para ello como objeto de estudio el caso de la ciudad de Soria, que en la época objeto de atención tenía un peso en las estructuras socioeconómicas y políticas de la Corona de Castilla mayor que el que conserva en la actualidad, muy disminuido como consecuencia de la acelerada despoblación de todo el territorio que la circunda, que en el pasado dio muestras de mucho mayor dinamismo, al que sin duda contribuyeron los judíos y los judeoconversos, como hemos tratado de demostrar.

Recibido: 03/07/2020

Aceptado: 07/09/2020 